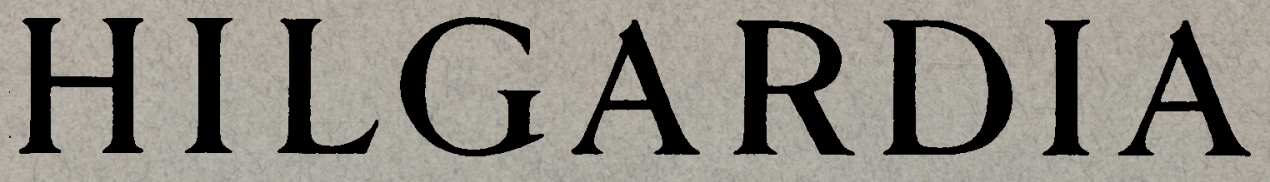

A Journal of Agricultural Science Published by the California Agricultural Experiment Station

\title{
THE GUMMING OF PHILLIPS CLING PEACHES
}

LUTHER D. DAVIS 


\title{
$\begin{array}{lllllllll}\text { H } & \text { I } & \text { L } & G & A & R & D & \text { I } & \text { A }\end{array}$
}

A Journal of Agricultural Science Published by

the California Agricultural Experiment Station

VoL. 11

JUNE, 1937

No. 1

\section{THE GUMMING OF PHILLIPS CLING PEACHES ${ }^{1}$}

\author{
LUTHER D. DAVIS ${ }^{2}$
}

\section{INTRODUCTION}

THE PRODUCTION OF GUM by stone fruits and stone-fruit trees is rather common. The gumming appears most often on the branches or trunks and is associated with injury from an organism, an insect, or a mechanical source. Gumming on the fruit is less common than that on the tree, and gumming restricted to certain varieties occurs even less frequently. The Phillips Cling, a leading canning peach, suffers from gumming of the last-mentioned class ; and since about 1927 the losses from this cause have constituted a major problem of the growers of this variety. This paper deals with the description and case history of the disease, together with experiments in its control.

\section{TYPES OF GUMMING}

At least four different types of gumming occur on the Phillips Cling. ${ }^{(2) 3}$ All types of gum exuding from the fruit seem to have one common characteristic : they are all clear and colorless. Stone ${ }^{(7)}$ has described a gum of similar appearance occurring on peaches.

Gumming from External Injury.-The peach, in common with most other stone fruits, will gum when subjected to an external injury such as an insect puncture, limb or leaf rub, or Coryneum (shot-hole) infection. A wide variety of gumming from one or more of these causes may be found on the Phillips Cling. The gum does not occur at any particular place on the periphery of the fruit and may appear at any time before the yellow undercolor begins to develop prior to harvest. The character

\footnotetext{
${ }^{1}$ Received for publication April 3, 1937.

${ }^{2}$ Assistant Professor of Pomology and Assistant Pomologist in the Experiment Station.

"Superscript numbers in parentheses refer to "Literature Cited" at the end of the paper.
} 
of the gummy mass seems to be determined very largely by the nature of the injury. It may vary from the small, inconspicuous threads of gum produced by an insect puncture to the rather large and sometimes spec-

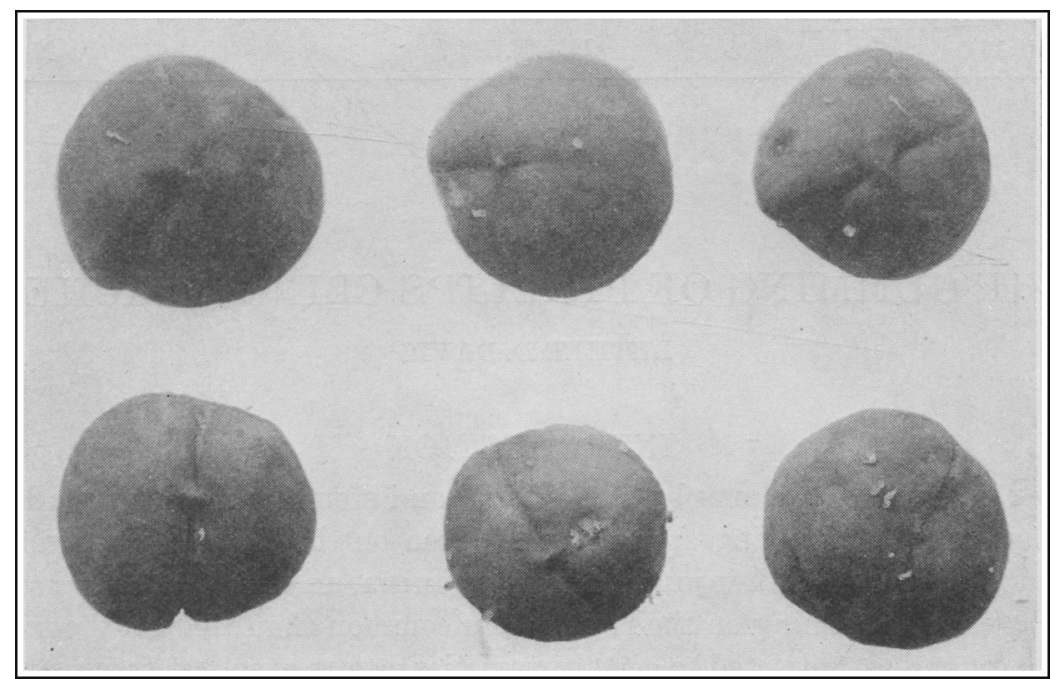

Fig. 1.-Mature Phillips Cling peaches showing gumming due to external injury.

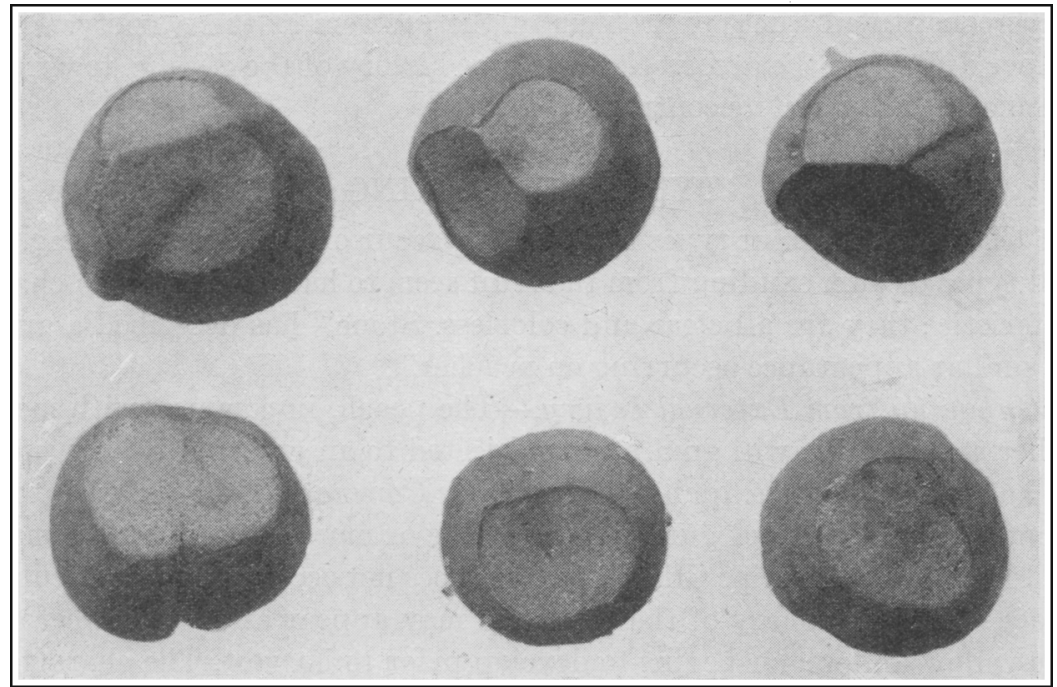

Fig. 2.-The same fruits as in figure 1, showing the extent of injury to the flesh beneath the gumming.

tacular mass produced by a greater injury. Figures 1, 2, and 3 illustrate some variations in the gummy mass. The extent of the damage to the 
flesh is also determined by the cause : sometimes the injury is only a few cells deep; in other cases, such as limb rubs, it may be many cells deep. This type of gumming is not restricted to the Phillips Cling variety.

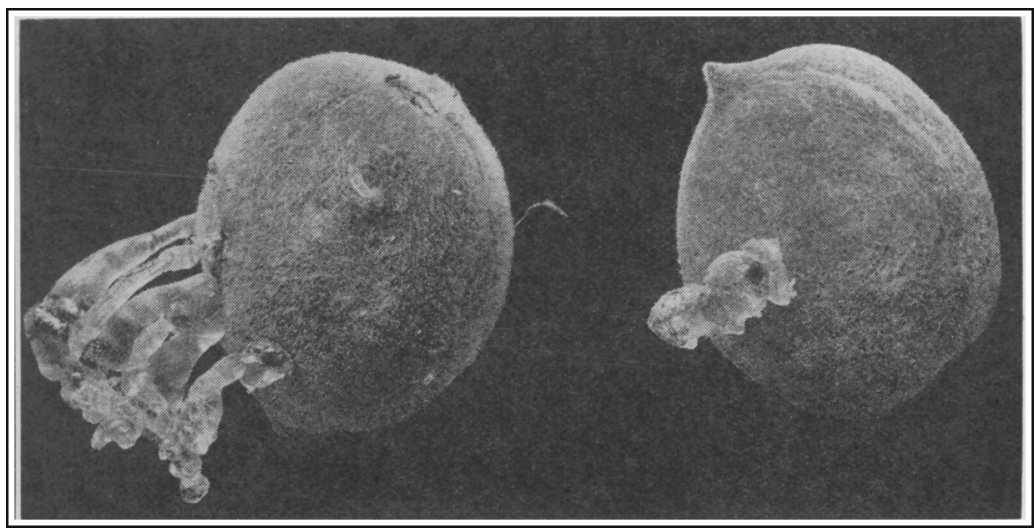

Fig. 3.-Young Phillips Cling peaches showing extreme cases of gumming due to external injury.

Early Suture Gumming.-A second type has been designated as early suture gumming, because of the time of appearance and the location of the gummy mass on the fruit. It occurs rather early in fruit development, when, or a little before, the pit begins to harden on the tip. The mass of gum is always large- sometimes half as large as the fruit-and is always located on the ventral suture. The mass, somewhat smooth and globular, extends through the flesh into the pit, which is split, and usually fills the pit cavity. The point of emergence is usually about halfway between the

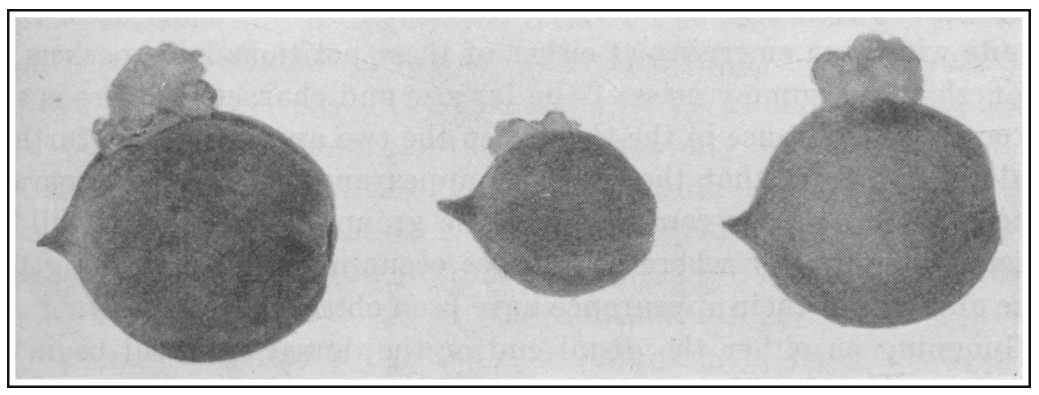

Fig. 4.-Early suture type of gumming on young Phillips Cling peaches.

basal and distal ends along the ventral suture, but may be at any point along the suture. Figures 4 and 5 show typical cases and the manner in which the gum extends into the pit. Since fruits thus affected shrivel and 
fall from the tree very soon after the gum has appeared on the surface, they do not constitute a problem for the grower at harvest time.

Distal and Dorsal Gumming.-A third type of gumming has been designated as distal and dorsal. This is distinguished from other types

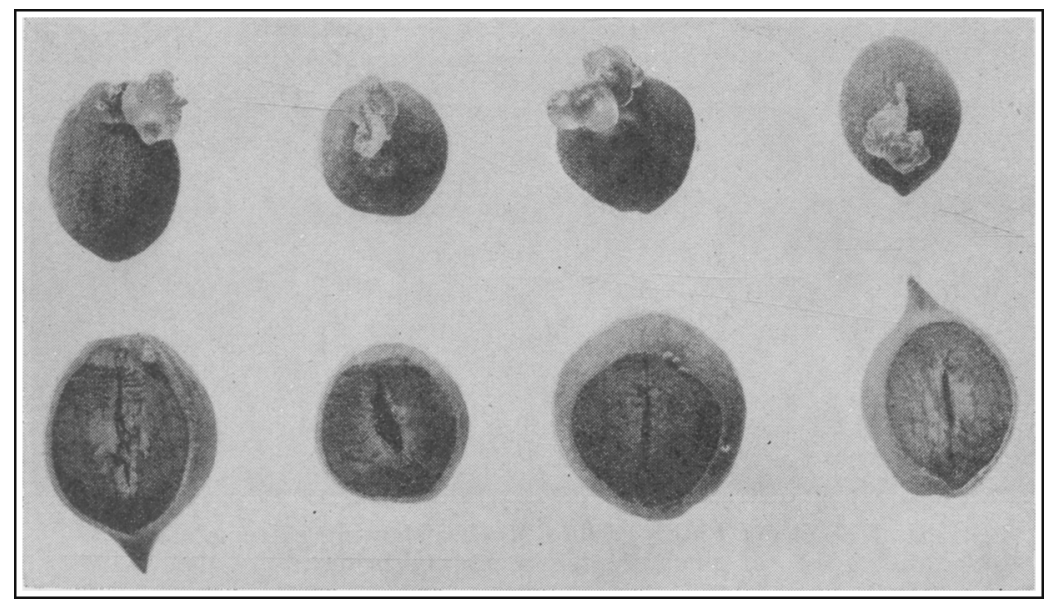

Fig. 5.-Early suture type of gumming on young Phillips Cling peaches, showing the variation in point of emergence and the gum-filled cavity of the pit, which is always split.

by a pocket in the flesh beneath the point where the gum emerges, by the size and character of the gummy mass, by its position on the fruit, and by the time of its appearance.

There may actually be two different types of gumming included in the third group. The gummy mass emerges at one of two positions in fruits placed under this heading. It may emerge near the pistil tip or on the dorsal side one-fourth to one-third the distance toward the basal end. Fruits with gum emerging at either of these positions have pockets in the flesh and a gummy mass of similar size and character. There is apparently no difference in the time when the two appear. Unless further evidence indicates that the point of appearance constitutes separate types, the two will be considered as one group, although they will be described separately where differences occur and data regarding the time and rate of their appearance have been obtained separately.

Gumming on either the distal end or the dorsal side will begin to appear during the third week after the date when the pit has begun to harden on the tip and a short distance along the ventral suture. This is two to three weeks after the early suture gumming has appeared.

In fruits affected with the distal and dorsal type the gumming is usually twisted and segmented, frequently ribbonlike. In young fruits it 
emerges from a slitlike opening, which is several times longer than wide and appears as though made by the point of a thin knife blade. Later in the season the dimensions are changed by growth so that in mature fruits the opening is more nearly isodiametric. Although, in this type, the gum mass varies greatly in size, it is rarely large as in the early suture type.

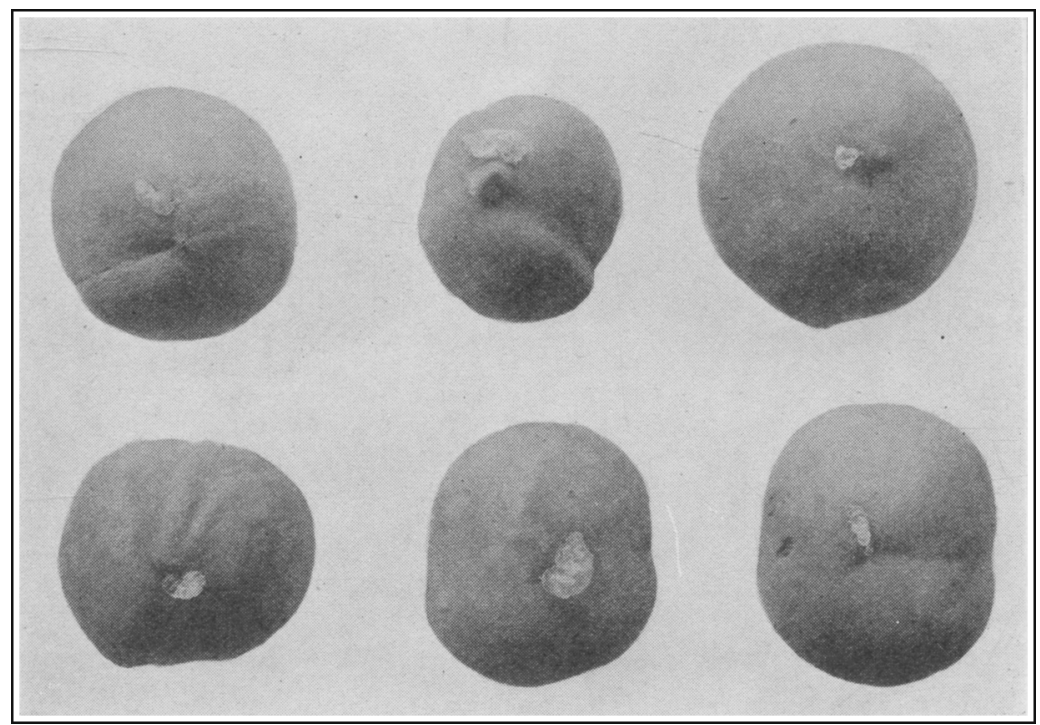

Fig. 6.-Mature Phillips Cling peaches with gumming in the distal position. The segmented, twisted nature of the gum is shown.

Figures 6,7 , and 8 show typical distal gum on mature and young fruits-its twisted and segmented nature. The segments suggest that each had been exuded during successive intervals and that time had elapsed between periods of exudation, so that the gum had become somewhat hardened on exposure to the lower humidity outside the fruit.

Figures 9 and 10 illustrate typical dorsal gum on mature and young peaches. Gum in this position is always associated with a mound arising abruptly from the regular periphery of the fruit. It always exudes at the base of the mound-that is, where the smooth periphery is broken by the hump in the flesh. The lower left-hand fruit in figure 10, showing gum exuding on two sides of the hump, is an unusual specimen. Gum usually exudes from but one side. It is also very unusual to find fruits with both distal and dorsal gumming, although occasionally they are found. Gumming in one position seems to preclude gumming in the other. Dorsal gumming shows the same twisting and segmentation as distal. 
The upper fruits in figure 7 are intermediate between typical distal and dorsal types. Each shows the break in the periphery of the fruit characteristic of dorsal gumming.

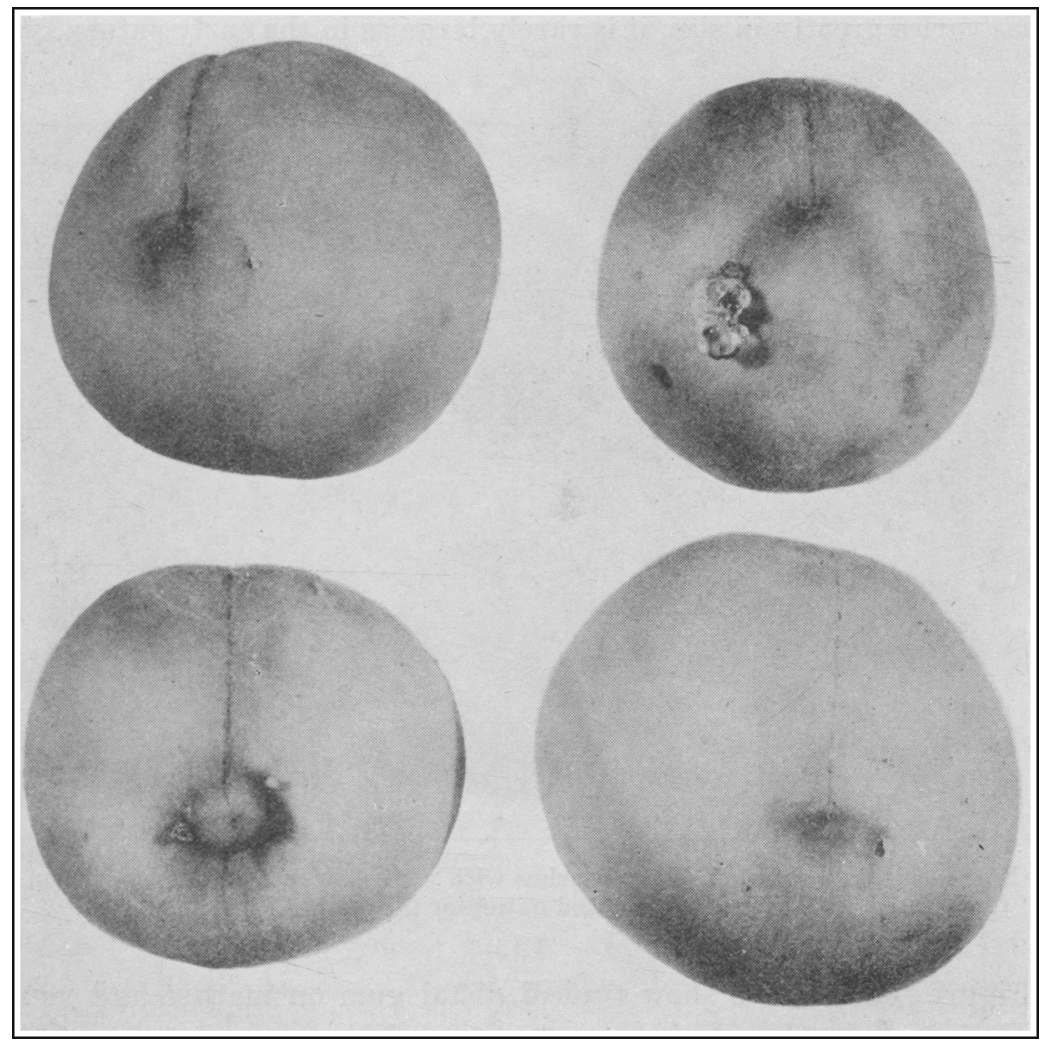

Fig. 7.-Mature Phillips Cling peaches showing variations of gumming in the distal position. The fruit in the lower left shows the greenish coloration sometimes occurring; that-in lower right is of a typical distal type with the gumming mass removed; the one in upper left shows a slight hump toward the dorsal side; that in upper right shows a hump more distinctly toward the dorsal side, with the gummy mass also toward that position.

Gummy fruit of the distal and dorsal types always have a pocket in the flesh beneath the point where the gum emerges. Figure 11 shows sections of the fruit through a pocket beneath dorsal gumming. The $\mathrm{V}$ shape of this pocket, as seen in cross or longitudinal section, with the apex of the $\mathrm{V}$ pointing toward the pit, is typical of many pockets occurring in fruits with gumming in this position.

The fruit on the lower right with a quarter section removed between cuts made at right angles through the hump shows a portion of the 
pocket curving toward the apex of the fruit. This particular variation does not, however, seem typical. The pocket in this type of gumming very much resembles a hollow cone filled with flesh, with its apex toward the pit, its base near the periphery of the fruit. It corresponds to the abrupt change in contour that causes the hump. Figure 12 shows the fruits illustrated in figure 6 when they are cut in cross section beneath

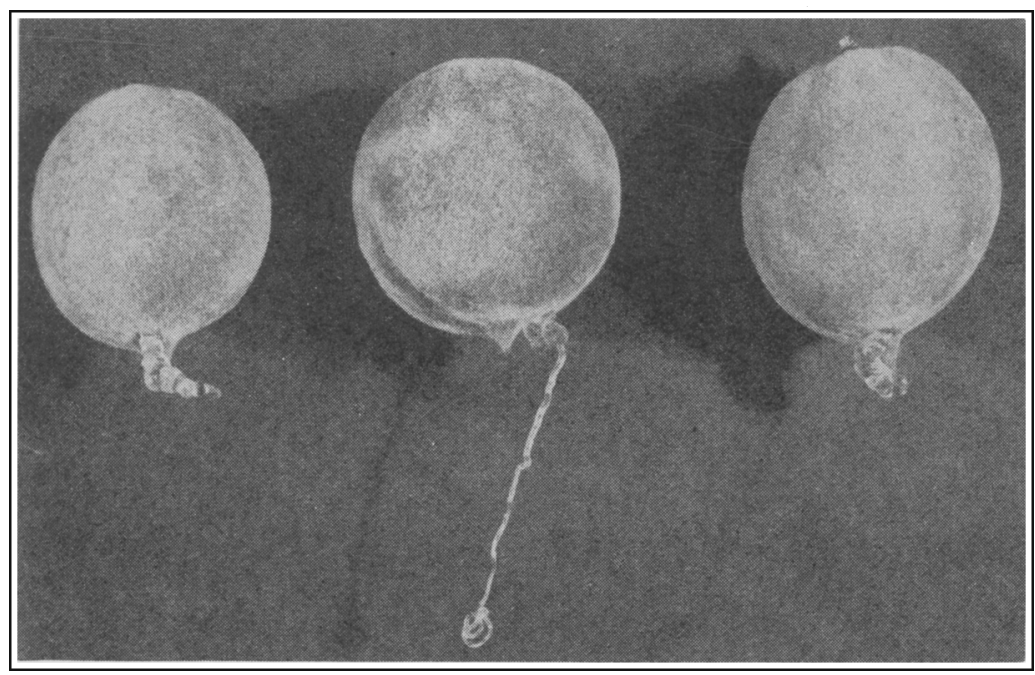

Fig. 8.-Young Phillips Cling.peaches with distal gum, showing its twisted, segmented, and ribbonlike character.

the point where the gumming emerges. The $\mathrm{V}$-shaped outline of the pocket is characteristic of many fruits with gumming in this position. The apex of the $\mathrm{V}$ always points towards the ventral suture.

The pockets vary in depth. Frequently the pocket lying beneath the hump of the dorsal type can be traced to the pit if one makes successive tangential sections through it. In other cases it does not extend so deeply. The pocket beneath the distal type usually extends as deeply into the flesh as the extreme tip of the pit, or a little deeper. Only infrequently, however, does it extend as deeply as the larger part of the pit.

The pocket is not so definite nor so large in young fruits as in mature ones. In young fruits very soon after the gum has appeared the pocket and adjacent flesh are brownish, "water-soaked," and full of gum. In mature fruits much of the discoloration has disappeared from the flesh; the pocket is larger and usually has gum only around its periphery. In many cases when successive cross sections are cut through the pockets of young fruits with gumming in the distal position, the cavity seems to progress over the fruit toward the dorsal side. In mature fruits this con- 
dition is less pronounced, perhaps because of the relative change in position as the fruit becomes larger and more nearly spherical. The latter observation suggests a possible close relation between distal and dorsal gumming with respect to their point of origin. Pockets in the flesh are

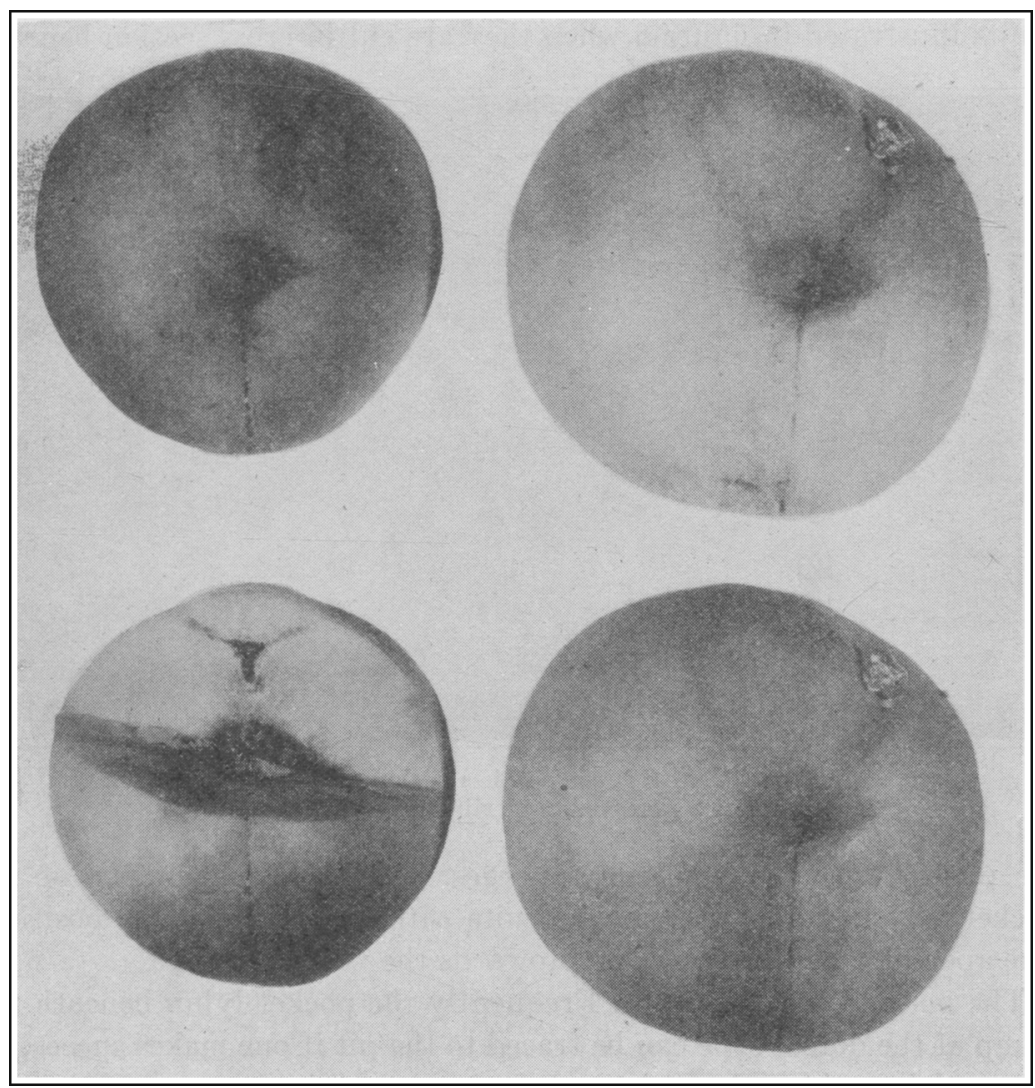

Fig. 9.-Mature Phillips Cling peaches with gumming in the dorsal position. The fruit on the upper left has no gum emerging, but has a hump in the flesh. The same fruit is shown in the lower left after being cut transversely through the hump.

not necessarily accompanied by an exudation of gum. Occasionally fruits are found with pockets but with no gum exuding. The presence of the cavity is indicated by a change in the regular periphery of the fruit, by a deeper green color, or by both (figs. 9 and 13).

Fruits with distal or dorsal gumming are the only ones with a pocket in the flesh. They develop and ripen normally. The pocket is so placed that when the fruit is halved along the suture before canning, a part of the pocket is contained in each half, rendering it unfit for first-grade 
fruit and necessitating some hand-cutting before it can be used at all. For this reason canners are loath to accept fruits with pocket gumming.

Late Ventral Gumming.-A fourth type of gumming, called late ventral, is characterized by a deep-green, water-soaked discoloration of the flesh on both sides of the ventral suture. Many small drops of gum exude from the flesh so that the surface of the discolored area feels rough. This

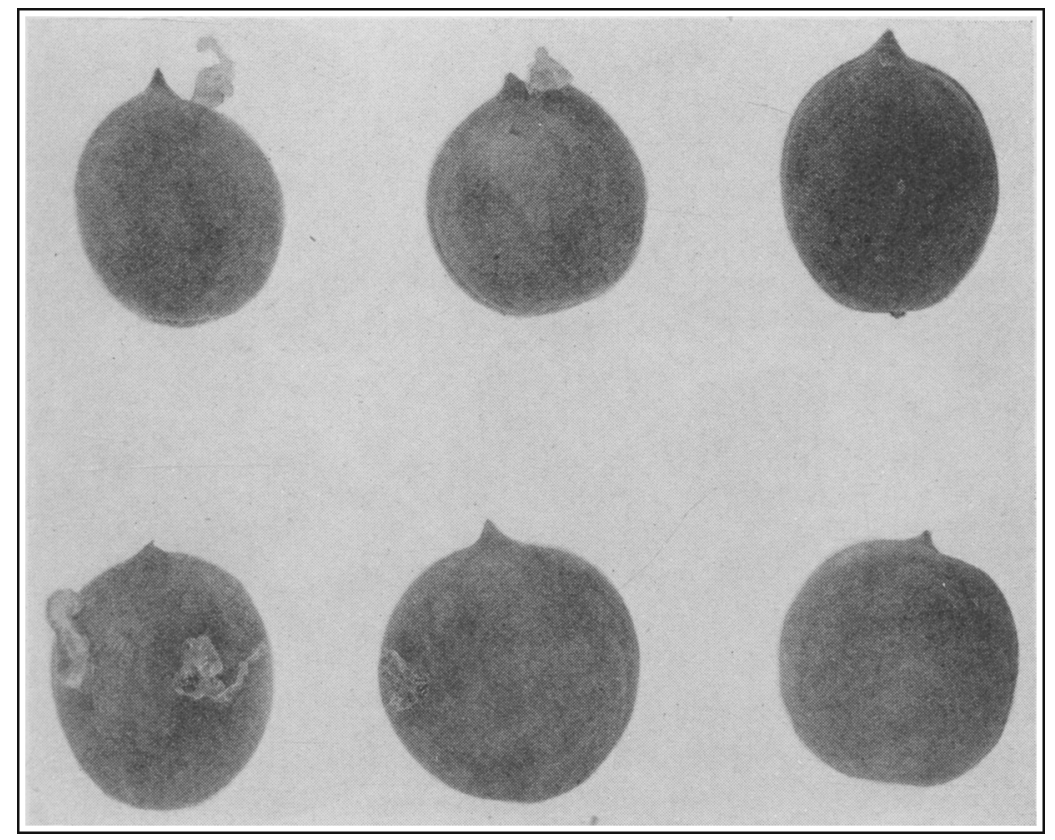

Fig. 10.-Young Phillips Cling fruits with gumming in the distal and dorsal positions.

granular feel of the beads of gum identifies the type in cases where the discoloration is not pronounced (fig. 14). Although there are no pockets in the flesh, the discoloration renders both halves unfit for a first-grade canned product.

The various types of gumming characteristic of the Phillips Cling and apt to cause a loss are illustrated in figure 15. The early suture type is not shown inasmuch as nearly all fruits with this type of gumming drop from the tree soon after the gum appears. Fruit 1 in this figure may be representive of another type not described here. A small mass of gum appears on the ventral suture a few weeks before harvest. Number 2the late ventral type-shows tiny drops of gum and a discolored area. Fruit 3 is distinctly dorsal. Number 4 illustrates a case apparently inter- 
mediate between the dorsal and distal positions. The hump lies on the dorsal side but extends down to and includes the pistil tip. Other considerations suggest that there may be no fundamental difference between distal and dorsal gumming. Additional evidence is necessary, however,

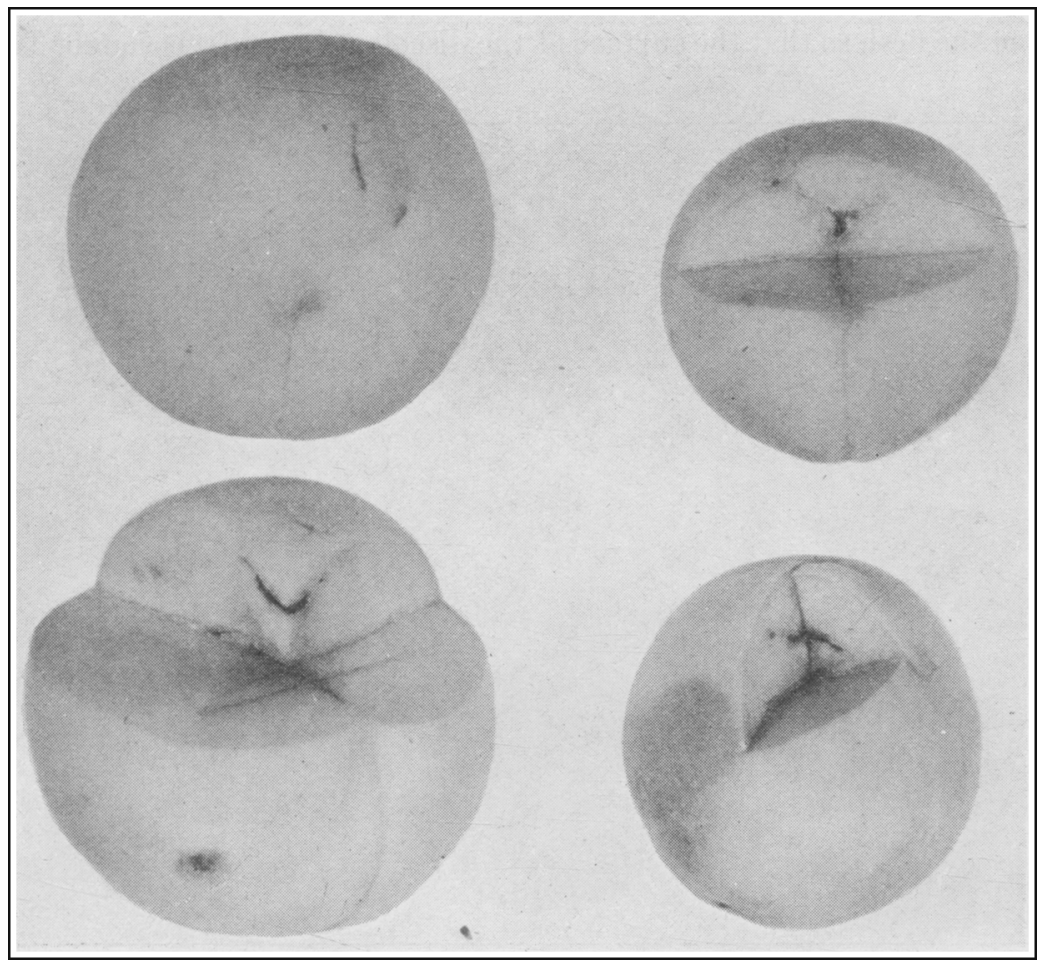

Fig. 11.-Mature Phillips Cling peaches with gumming in the dorsal position, showing the pocket when cut in various planes.

before such a point can be definitely established. Numbers 5 and 6 illustrate gum in the distal positions.

\section{DISTRIBUTION OF TYPES}

Data have been obtained upon the percentage distribution of the various types. Fruits with gumming caused by external injury have not been included. The following data, for 1933, show that the early suture type appears in advance of the third and fourth types and also that many of these fruits soon drop. In 1933 all the gummy fruits were removed from certain trees at weekly intervals from June 8 throughout the season. On this date the early suture type constituted 80 per cent of all the gummy fruits removed; on June 15, 51 per cent; and on June 22, 9.7 per cent. 
No early suture type was found in any of the subsequent collections. This type made up 9.4 per cent of the total number of gummy fruits removed from these trees during the season. Approximately 5,000 gummy fruits were collected from other trees in the same orchards later-from about

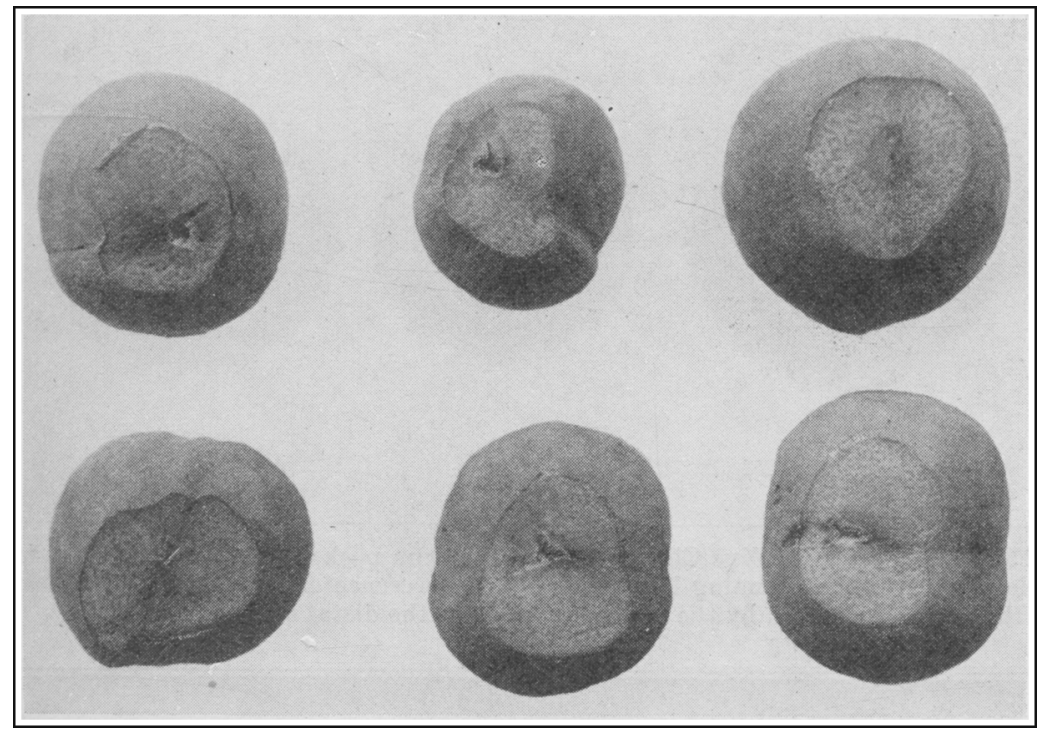

Fig. 12.-The fruits shown in figure 6 cut in cross section beneath the point where the gum emerges.

July 15 until harvest. Only five early-suture-type gums were among these fruits, a fact indicating that they fall from the tree soon after the gum appears.

The data in table 1 show the percentage distribution of the types considered characteristic of the Phillips Cling and troublesome to the grower.

TABLE 1

Percentage Distribution of Distal, Dorsal, and Ventral Suture TYPES OF GUMMING

\begin{tabular}{|c|c|c|c|c|c|c|c|c|c|}
\hline Year & $\begin{array}{l}\text { Total } \\
\text { fruits }\end{array}$ & $\begin{array}{c}\text { Distal } \\
\text { position }\end{array}$ & $\begin{array}{c}\text { Dorsal } \\
\text { position }\end{array}$ & $\begin{array}{l}\text { Ventral } \\
\text { position }\end{array}$ & Year & $\begin{array}{l}\text { Total } \\
\text { fruits }\end{array}$ & $\underset{\text { position }}{\text { Distal }}$ & $\begin{array}{c}\text { Dorsal } \\
\text { position }\end{array}$ & $\begin{array}{l}\text { Ventral } \\
\text { position }\end{array}$ \\
\hline 1932. & 2,407 & $\begin{array}{c}\text { percent } \\
73.8\end{array}$ & $\begin{array}{c}\text { percent } \\
12.4\end{array}$ & $\begin{array}{c}\text { percent } \\
13.8\end{array}$ & 1935. & 7,691 & $\begin{array}{c}\text { percent } \\
79.1\end{array}$ & $\begin{array}{c}\text { percent } \\
8.6\end{array}$ & $\begin{array}{c}\text { percent } \\
12.3\end{array}$ \\
\hline 1933. & 9,115 & 69.6 & 18.3 & 12.1 & 1936. & 7,534 & 75.5 & 13.2 & 11.3 \\
\hline 1934. & 3,804 & 82.0 & 6.3 & 11.7 & All years. . & 30,551 & 76.2 & 11.4 & 12.4 \\
\hline
\end{tabular}

The fruits from which these data were obtained were collected after the time when the early suture gumming would have fallen. Fruits with distal or dorsal gumming are separated in this table. 
Table 1 includes all the fruits that were classified according to type during a period of five years. Distal gumming accounts for a very large proportion of all those affected. Fruits with gumming on the ventral suture comprise a very constant proportion-about 12 per cent each

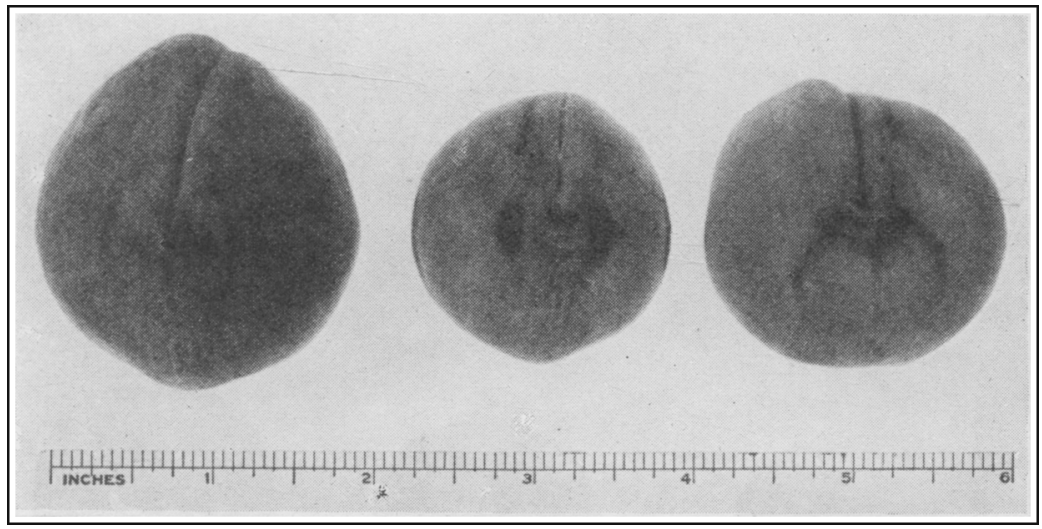

Fig. 13.- Young Phillips Cling peaches with gum pockets on the distal end, from which, however, no gumming has emerged. The presence of the pockets is indicated by the darker color and by the depression around the distal end.

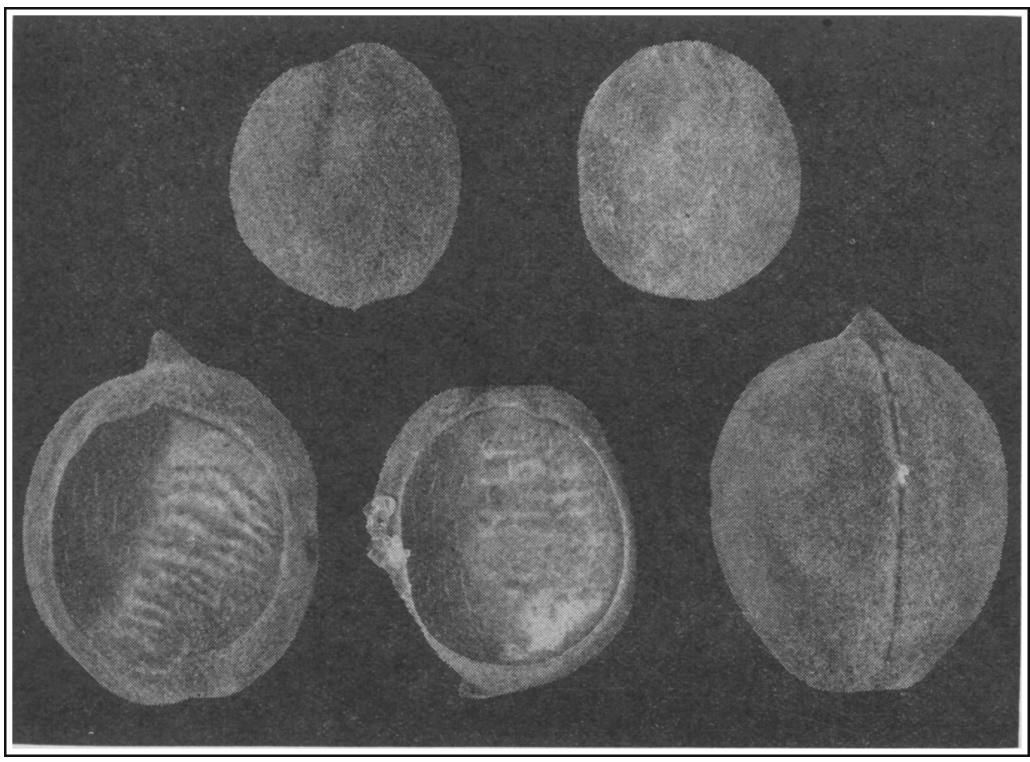

Fig. 14.- Young Phillips Cling peaches with late ventral type of gumming.

year. In the proportion in the dorsal position, there is considerable variation reflected closely by the change in amount in the distal position. 
Perhaps the variations are caused by the intermediate cases shown in number 4 of figure 15, or there may be a variation between these two groups from year to year.

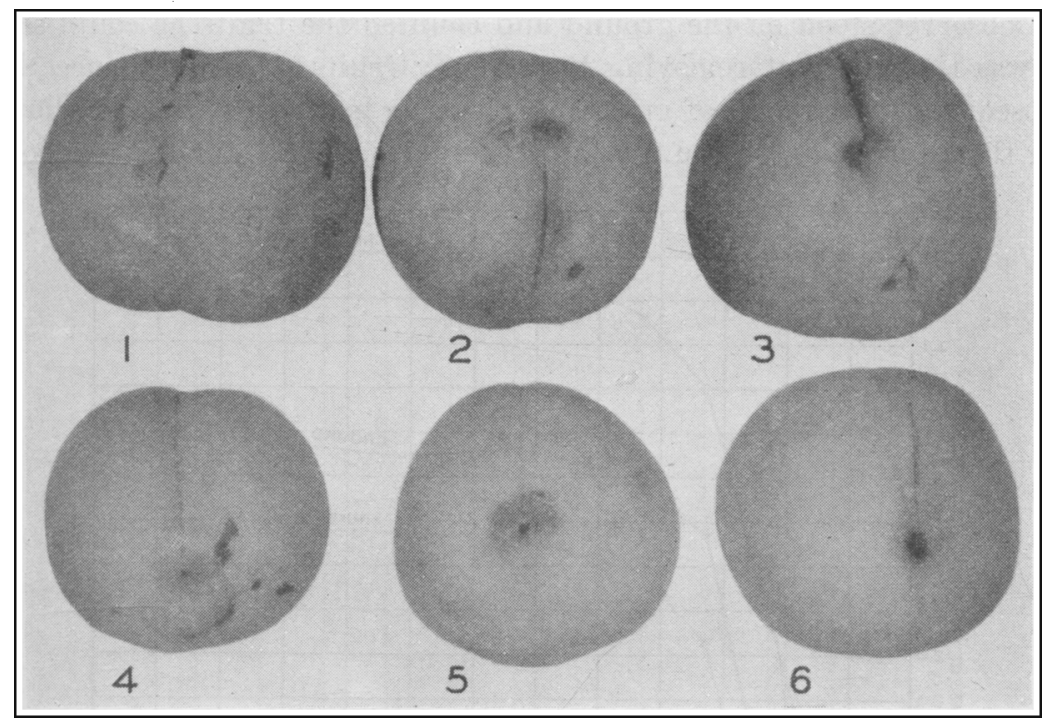

Fig. 15.-Mature Phillips Cling peaches with various types of gumming characteristic of this variety. See text for discussion of the individual fruits.

\section{TIME AND RATE OF APPEARANCE OF GUMMING}

It has been indicated earlier in this paper that gumming, except the external-injury type, takes place at definite periods in fruit development. As shown by data already presented, all the fruits of the early suture type appear within a relatively short time and then drop off. Gumming of this type begins when the pit begins to harden on the tip or a few days earlier. The beginning of pit hardening has been chosen as a reference point in the production of gumming, being easily determined in the field and being found at a definite period in fruit development. At this time the peach is entering the second period of growth and the embryo may be seen macroscopically ${ }^{(5,9)}$ Ragland ${ }^{(6)}$ has described pit hardening in this variety. The date when the hardening and the color change have progressed about $3 / 8$ inch from the tip along the ventral suture has been chosen as the reference point. This date is easily determined in the field by cutting a number of fruits through the tip and distal end of the ventral suture with a sharp knife.

The following data will deal only with distal, dorsal, and ventral gumming. In the earlier investigations regarding the time and rate of ap- 
pearance of gumming the data were obtained by three methods. By one method all gummy fruits were picked off certain trees at regular intervals, usually a week apart. In the second method dated metal rim tags were placed on all new gummy fruits at regular intervals. In the third, the observer stood on the ground and counted the fruits he could see. It was thought that removing the gummy fruits might influence the subsequent appearance of gumming. Tagging gummy fruits and allowing them to remain on the tree would serve as a check for this method.

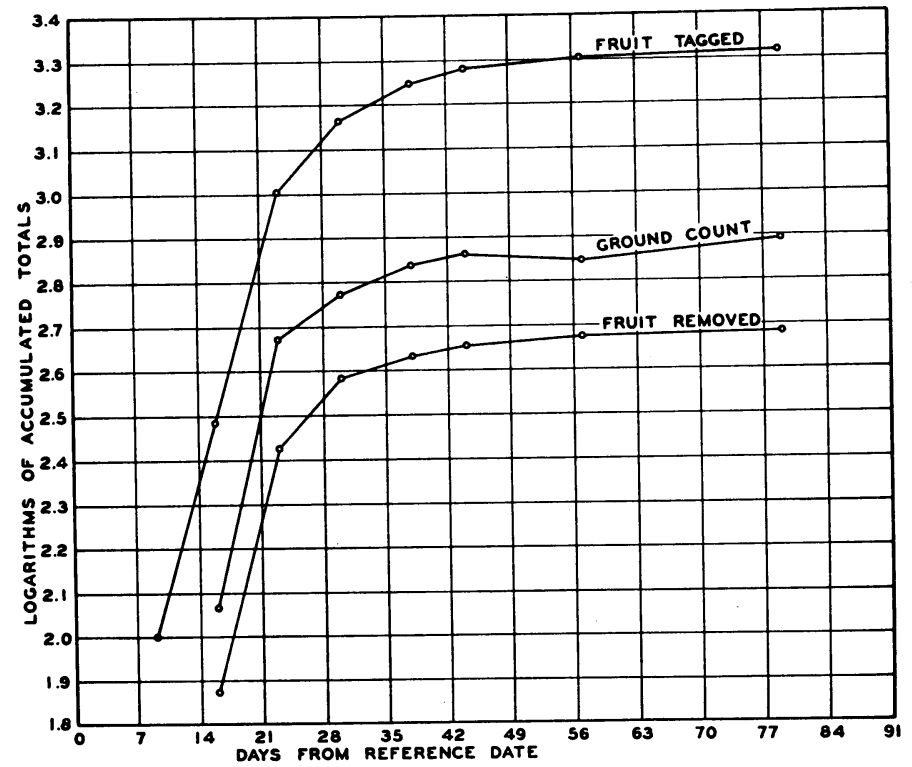

Fig. 16.-Comparison of three methods of obtaining data on the appearance of gumming.

Counting gummy fruits from the ground was used in a preliminary manner to develop a method of obtaining data upon large numbers of trees. These methods were used in 1931, 1932, and 1933. The 1932 data, presented in figure 16, are typical. They are plotted as logarithms of the number of fruits involved. As the curves obtained by the three methods are almost exactly parallel, any one of the three is satisfactory in obtaining information regarding the appearance of gumming.

Each method has certain advantages. Counting the gummy fruits from the ground is fast and permits large numbers of trees to be used. It does not permit a ready classification of the different types of gumming, does not account for any fruits that may fall, and does not allow data to be obtained on all the gummy fruits on the trees. Placing dated tags on gummy fruits at stated intervals is laborious and time-consum- 
ing. Harvesting the tagged fruits does allow the different types of gumming to be classified and the mature fruits to be examined. Periodic removal of the gummy fruits is much less laborious and time-consuming than placing the tags. It allows the different types of gum to be classified and the fruits to be examined soon after the gumming has appeared. The latter method has been used most extensively in obtaining the data on the appearance of gumming.

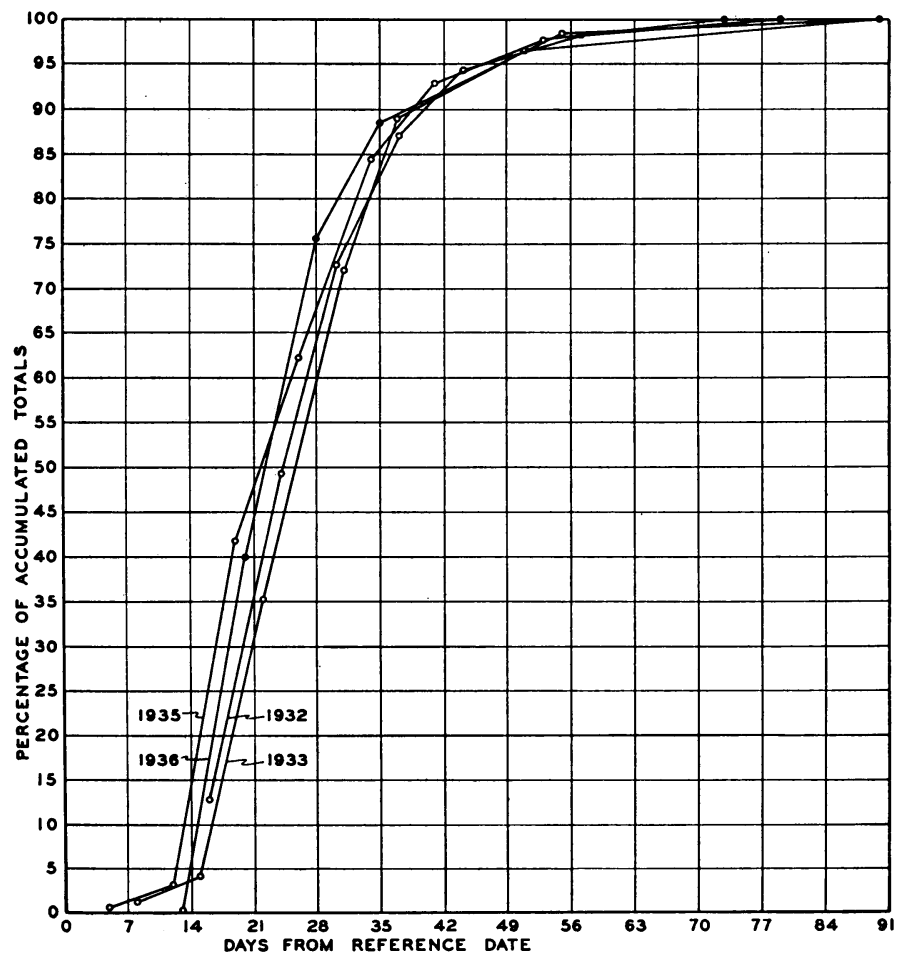

Fig. 17.-Appearance of gumming as percentage of the accumulated totals.

Figure 17 presents the data on the appearance of gumming as percentage of total gummy fruits for 1932, 1933, 1935, and 1936. The zero of the abscissa is the date selected from the pit-hardening observations as the reference date. The number of days from this date are plotted along the abscissa. This reference point varies with the seasons. In 1929 it was May 25; in 1930, May 15; in 1931, May 10; in 1932, May 18; in 1933, May 31 ; in 1934, May 7 ; in 1935, June 1; and in 1936, May 20.

As figure 17 shows, very little of the total gumming has occurred during the first 15 days after the reference date. Soon after this interval the number of gummy fruits increases rapidly for about 20 days, so that at 
the end of about 35 days after the reference date approximately 85 per cent of all the gumming will have taken place. The rapid upswing in the number of gummy fruits is very pronounced, and the time when it will occur can be calculated rather accurately from the reference date. In

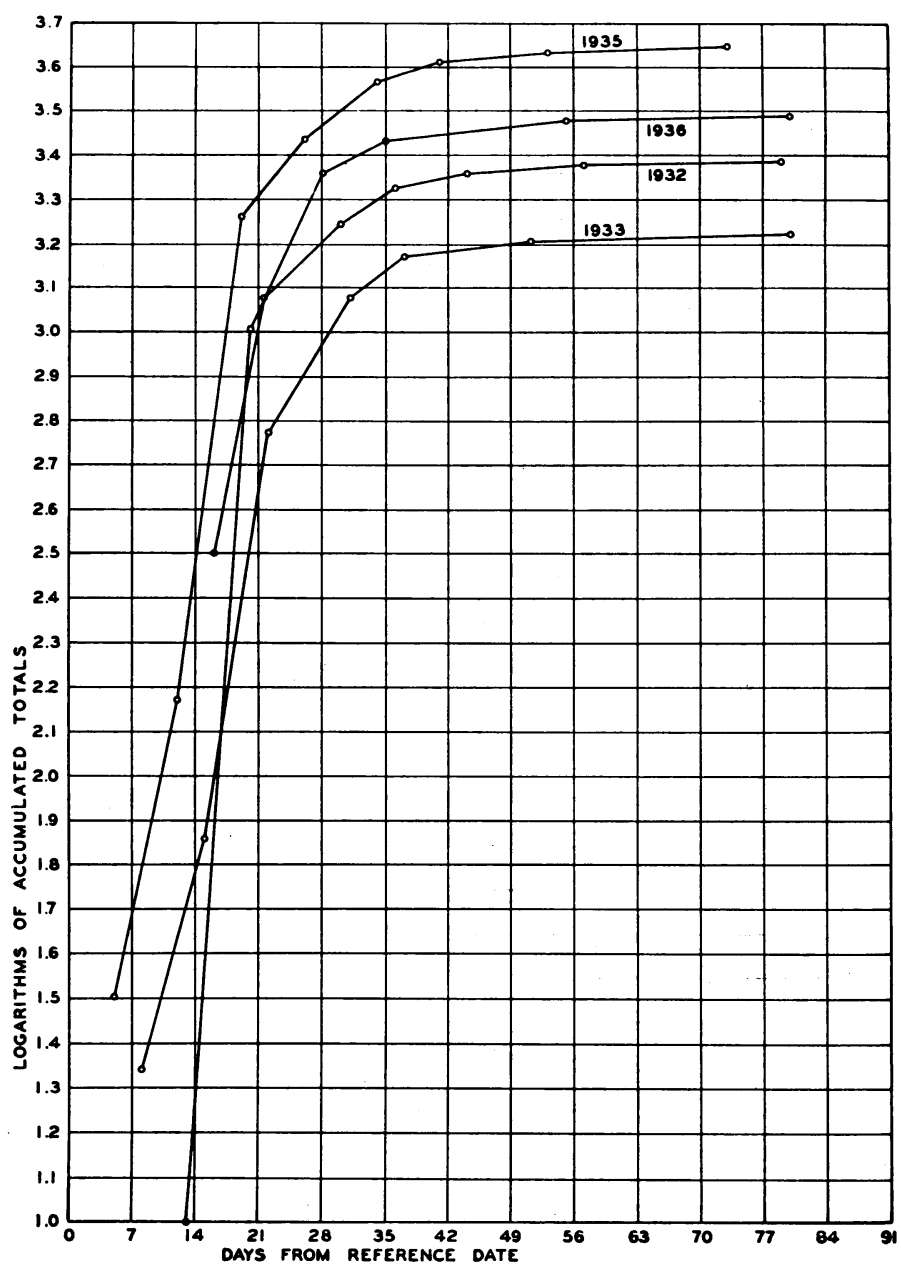

Fig. 18.-Number of gummy fruits plotted as logarithms of the accumulated totals.

1935, from 35 trees, 32 gummy fruits were removed on June 6, 5 days after the reference date; 117 on June 13; and 1,698 on June 20. In 1936, from the same 35 trees, ten gummy fruits were removed on June 2, 13 days after the reference date; and 1,225 on June 9. In 1934 only four collections were made at periods previously determined at the time the 
reference date was selected. A total of 3,794 gummy fruits were gathered. Of this amount 4 per cent was collected on May 17-18, 10 days after the reference date; 77 per cent on June 12-13, 36 days after the reference date ; 13 per cent on July 14-15; and 6 per cent just before harvestabout August 15. The consistent behavior of these data is emphasized by the fact that the same trees and orchards have not been used in the different years and that the number of gummy fruits gathered for these particular data has varied from 940 in 1931 to 4,438 in 1935. Yet the characteristics regarding the time and rate of appearance of the gumming for different orchards and for varying numbers of fruits are very similar.

Figure 18 presents the data for the appearance of gumming in which the logarithms of the total number of gummy fruits that have appeared by a given date are plotted as ordinates. This figure shows the very close parallelism of the curves for the four years, although the amount of gumming has varied widely.

\section{SPLIT-PIT AND EMBRYO ABORTION}

The presence of gumming on the fruit has been found to be associated with a high proportion of split-pits and aborted embryos.

Fruits showing gumming of the early suture type always have splitpits, aborted embryos, and pit cavities filled with gum.

Fruits with distal, dorsal, or ventral gumming do not all have split-pits nor aborted embryos, although they do show a high percentage of both.

Aborted embryos as discussed here may not include all those that will not germinate. ${ }^{(8)}$ They are considered to be those whose development has been stopped before the condition in which they would normally appear at harvest. At the latter time a normal embryo will have filled muchalthough not necessarily all-of its seed coat; the embryo will be firm, white, and somewhat sticky when the seed coat is removed; and the seed coat will be light brown. In contrast, an aborted embryo, in mature fruits, will have a dark-brown seed coat, usually collapsed or partially so. In many cases all that remains of the embryo is its epidermal layer. In other cases the embryo is dull-colored, rubbery, semitranslucent, and slimy when removed from the seed coat. In earlier stages of the fruit an aborted embryo may be distinguished by the brown color of the vascular system radiating from the chalazal end in contrast to the glistening white of the normal seed. The size of the two embryos may not be much different at this stage. The normal embryo, however, has the characteristic stickiness mentioned above in contrast to the sliminess of the aborted one. In all probability this conception would rate as normal many embryos that would be considered aborted if their ability to germinate were the criterion used. 
The following data have been obtained to verify our judgment in segregating aborted embryos early in the season. In 1932 gummy fruits on certain trees were tagged at regular intervals. On other trees all the gummy fruits were removed on the same dates. At harvest time the tagged fruits had 80 per cent aborted embryos; the fruits removed at intervals had 70 per cent. In 1933 large composite samples of gummy fruits were collected about July 1 , when approximately 80 per cent of the gumming had appeared. Other large samples, from different trees,

TABLE 2

Percentage of Split-Pits Among Gummy and Nongummy Fruits

\begin{tabular}{|c|c|c|c|c|c|c|c|}
\hline \multirow{2}{*}{ Year } & \multicolumn{5}{|c|}{ Gummy fruits, per cent of split-pits in each position } & \multicolumn{2}{|c|}{ Nongummy fruits } \\
\hline & $\begin{array}{c}\text { Total } \\
\text { fruits } \\
\text { examined }\end{array}$ & Distal & Dorsal & Ventral & All types & $\begin{array}{c}\text { Total } \\
\text { fruits } \\
\text { examined }\end{array}$ & $\begin{array}{l}\text { Per cent } \\
\text { split-pits }\end{array}$ \\
\hline 1929. & 1,100 & $\cdots$ & ... & $\ldots$ & 59.6 & 440 & 41.6 \\
\hline $1930 \ldots \ldots \ldots \ldots \ldots \ldots \ldots$ & 797 & ... & ... & $\ldots$ & 66.3 & 1,014 & 5.5 \\
\hline $1931 \ldots \ldots \ldots \ldots \ldots \ldots \ldots \ldots$ & 1,779 & $\ldots$ & $\ldots$ & $\ldots$ & 41.3 & 1,086 & 1.1 \\
\hline $1932 \ldots \ldots \ldots \ldots \ldots \ldots \ldots \ldots$ & 4,157 & $\ldots$ & $\ldots$ & $\ldots$ & 44.2 & 1,964 & 21.8 \\
\hline $1933 \ldots \ldots \ldots \ldots \ldots \ldots \ldots \ldots$ & 5,553 & 55.0 & 61.6 & 72.4 & 58.0 & 446 & 7.6 \\
\hline $1935 \ldots$ & 1,160 & $\ldots$ & $\ldots$ & $\ldots$ & 62.1 & $\ldots$ & $\ldots$ \\
\hline $1935^{*}$. & 2,255 & 17.8 & 19.3 & 14.0 & 17.3 & 2,090 & 3.0 \\
\hline $1936^{*}$ & 3,331 & 29.3 & 33.0 & 27.6 & 31.4 & 2,974 & 9.5 \\
\hline
\end{tabular}

* These data for 1935 and 1936 are for gummy fruits picked soon after the gumming had occurred. Nongummy fruits for comparison were picked from the same trees at the same time.

were collected about a month later; and again in about a month a third collection was made. The last collection approximated harvest. The data follow : first collection 86 per cent embryo abortion; second collection 94 ; third collection 93. In 1935 two large collections of gummy fruits were made from different groups of trees in the same orchards. The first was made about June 27 , a date near the end of the steep part of the curve for the appearance of gumming ; the second, just before picking. In the first collection 85 per cent of the embryos were aborted; in the second 95 . Although, as will be shown later in this paper, there are differences in the percentage of aborted embryos among individual trees, the data given above show that an examination of the embryo condition at the time gumming has occurred will yield a figure approximately 90 per cent of that which would be obtained by a similar examination at maturity. At the earlier time, evidence of abortion either was not pronounced enough for the embryos to be correctly sorted, or abortion in a certain percentage of cases occurred after the date of the examination. Since the abortion at gumming time is so high a proportion of that at maturity, examination at the earlier date is apparently justified, and is advantageous for other reasons. 
Split-Pit.-Table 2 presents the data for the percentage of split-pit in gummy fruits and in fruits without gumming. Where the types have been separated the data are arranged so that the percentage of split-pit is shown for each type as well as for all the gummy fruits. The data for 1929 to 1933 inclusive and the first line of 1935 are for random samples collected at harvest or just before harvest. The second line of 1935 and that for 1936 were obtained by removing all the gummy fruits from certain trees a few days after gumming had begun. Approximately the

TABLE 3

Embryo Abortion in Gummy and Nongummy Fruits

\begin{tabular}{|c|c|c|c|c|c|c|c|c|}
\hline \multirow{2}{*}{ Year } & \multicolumn{4}{|c|}{ Gummy fruits } & \multicolumn{4}{|c|}{ Nongummy fruits } \\
\hline & $\begin{array}{c}\text { Total } \\
\text { fruits } \\
\text { examined }\end{array}$ & $\begin{array}{l}\text { Per cent } \\
\text { aborted in } \\
\text { split-pits }\end{array}$ & $\begin{array}{c}\text { Per cent } \\
\text { aborted in } \\
\text { nonsplit }\end{array}$ & $\begin{array}{c}\text { Total } \\
\text { per cent } \\
\text { aborted }\end{array}$ & $\begin{array}{c}\text { Total } \\
\text { fruits } \\
\text { examined }\end{array}$ & $\begin{array}{c}\text { Per cent } \\
\text { aborted in } \\
\text { split-pits }\end{array}$ & $\begin{array}{c}\text { Per cent } \\
\text { aborted in } \\
\text { nonsplit }\end{array}$ & $\begin{array}{l}\text { Total } \\
\text { per cent } \\
\text { aborted }\end{array}$ \\
\hline 1929. & 1,100 & 93.7 & 91.0 & 92.5 & 440 & 63.4 & 19.1 & 37.5 \\
\hline 1930. & 797 & 89.7 & 54.7 & 77.8 & 1,014 & 64.0 & 6.8 & 9.9 \\
\hline $1931 \ldots$ & 1,779 & 96.6 & 66.2 & 78.8 & 1,086 & $\ldots$ & 0.8 & $\ldots$ \\
\hline 1932. & 4,157 & 86.6 & 60.4 & 72.0 & 1,964 & 68.1 & 12.2 & 24.9 \\
\hline $1933 \ldots$ & 9,100 & $94.8^{*}$ & $63.2^{*}$ & 81.2 & 3,253 & $64.8 \dagger$ & $9.7 \dagger$ & 7.9 \\
\hline $1934 \ldots$ & 3,611 & 98.3 & 86.2 & 90.3 & $\ldots$ & $\ldots$ & $\ldots$ & $\ldots$ \\
\hline $1935 \ldots$ & 2,454 & $\ldots$ & $\ldots$ & 90.0 & 2,014 & $\ldots$ & $\ldots$ & 33.1 \\
\hline $1936 \ldots$ & 6,338 & 99.3 & 94.9 & 94.7 & 3,941 & 75.2 & 16.7 & 20.4 \\
\hline
\end{tabular}

* Data based on 5,553 gummy fruits separated according to split-pit.

† Data based on 446 nongummy fruits separated according to split-pit.

same number of nongummy fruits were also removed from these trees. It will be seen that mature gummy fruits have a very high percentage of split-pits, much higher than comparable nongummy ones. The percentage of split-pits among the young gummy fruits collected in 1935 and 1936 is much less than that for mature fruits of other years, yet much higher than for comparable nongummy fruits. The data for the two groups of gummy fruits collected in 1935 should also be comparable. They were collected in the same orchards, different trees being used, however, for each collection, so that the collection made just before harvest (first line for 1935) would contain all the gummy fruits that had appeared during the season. The wide difference in the percentage of split-pit (62.1 for mature fruits and 17.3 per cent for fruits on which gumming had recently occurred) indicates that gumming, on a certain proportion of fruits at least, occurs before there is any easily visible evidence of splitpit. The periodic collections produced some supporting evidence.

Abortion of the Embryo.-Table 3 presents the data as percentages of embryo abortion in gummy and nongummy fruit. The data for the fruits with split-pit are presented separately from those for the nonsplit fruits, to show the effect of splitting and to prevent the data for the gummy 
fruits from being distorted by the large percentage of split-pits among them. In certain years all the fruits collected were not divided according to the split-pit condition. These data are indicated in the table.

Table 3 allows comparison between the percentage abortion among split and nonsplit fruits in the same group, between the split-pits or those not split in the two groups, and between percentage embryo abortion of large samples of gummy and nongummy fruits. Split-pit fruits have more aborted embryos than do those not split, a condition previously reported by Ragland..$^{(8)}$ The difference between the amount of abortion in split and unsplit fruits is much greater, however, in the nongummy fruits. A comparison of the amount of embryo abortion of split-pit, nonsplit, or total fruits shows that the gummy fruits always have a greater proportion than the nongummy. The intimate association of gumming and embryo abortion may be more clearly illustrated if we consider gummy and nongummy fruits whose pits are not split. The possible influence of split-pit upon abortion would be removed by such a consideration. As this comparison shows, many more aborted embryos appear among the nonsplit gummy fruits than among those without gumming. Further evidence of the association between gumming and embryo abortion may be shown by considering the ratio of the percentage abortion of split and nonsplit fruits in gummy and nongumming groups. The largest ratio of this kind for gummy fruits is 1.64 in 1930. In 1929 and 1936 the ratio is almost unity. Among nongummy fruits it varies from 3.3 to 9.4. If we may assume that splitting would cause the same amount of abortion in both gummy and nongumming fruits, the close association of gumming and embryo abortion can be seen from the foregoing comparison.

Table 3 does not segregate the types of gumming with the percentage of abortion in each. Such a record has, however, been kept for several years. The data for 1933 are typical of those obtained. Among the distal and dorsal types, the split-pit fruits have about 95 per cent aborted embryos; the nonsplit only about 60 . In the ventral type there is much over 90 per cent abortion in both split and nonsplit fruits. Very rarely is a normal embryo found among fruits with ventral gumming. The normal embryos in gummy fruits are very largely accounted for by nonsplit fruits of the distal and dorsal types.

The intimate association of embryo abortion with gumming is not confined to the Phillips Cling. In 1933 gummy fruits were collected from the Johnson, Peak, Paloro, and Levy varieties; the total varied from 40 to 200. Embryo abortion of gummy fruits in these samples ranged from 96 to 100 per cent; abortion in comparable samples of nongummy fruits, from 2 to 8 per cent. 


\section{SPLIT-PIT AND EMBRYO ABORTION OF INDIVIDUAL TREES}

The data in tables 2 and 3 are for random samples of fruits collected at harvest or for periodic collections of gummy and nongummy fruits. In the latter case all the gummy fruits were collected from certain trees from which a like number of nongummy ones were selected at random. These data show the close association between gumming, embryo abor-

TABLE 4

Comparisons of Percentage of Split-Pit and Aborted Embryos Among Trees High aNd Low in Gumming

\begin{tabular}{|c|c|c|c|c|c|c|c|c|c|c|}
\hline \multirow{2}{*}{$\begin{array}{c}\text { Ranch and } \\
\text { year }\end{array}$} & \multirow{2}{*}{$\begin{array}{c}\text { Tree } \\
\text { num- } \\
\text { ber }\end{array}$} & \multirow{2}{*}{$\begin{array}{l}\text { Total } \\
\text { fruits } \\
\text { on tree }\end{array}$} & \multirow{2}{*}{$\begin{array}{l}\text { Per cent } \\
\text { gummy }\end{array}$} & \multirow{2}{*}{$\begin{array}{l}\text { Per cent } \\
\text { split-pit } \\
\text { in non- } \\
\text { gummy } \\
\text { fruits }\end{array}$} & \multicolumn{2}{|c|}{$\begin{array}{l}\text { Per cent embryo } \\
\text { abortion among } \\
\text { nongummy fruits }\end{array}$} & \multicolumn{2}{|c|}{$\begin{array}{l}\text { Per cent embryo } \\
\text { abortion among } \\
\text { gummy fruits }\end{array}$} & \multirow{2}{*}{$\begin{array}{l}\text { Per cent } \\
\text { abortion } \\
\text { accounted } \\
\text { for by } \\
\text { gummy } \\
\text { fruits }\end{array}$} & \multirow{2}{*}{$\begin{array}{l}\text { Per cent } \\
\text { split-pit } \\
\text { accounted } \\
\text { for by } \\
\text { gummy } \\
\text { fruits }\end{array}$} \\
\hline & & & & & $\underset{\text { pit }}{\text { Split- }}$ & $\begin{array}{l}\text { Non- } \\
\text { split }\end{array}$ & $\begin{array}{l}\text { Split- } \\
\text { pit }\end{array}$ & $\begin{array}{l}\text { Non- } \\
\text { split }\end{array}$ & & \\
\hline Chandler, 1933 & B-10 & 373 & 41.6 & 10.1 & 82.0 & 10.0 & 100.0 & & 75.2 & 79.0 \\
\hline Chandler, 1933 & B-7 & 443 & 24.8 & 8.1 & 44.0 & 9.0 & 100.0 & & 67.2 & 68.0 \\
\hline Chandler, 1933 & B-5 & 897 & 3.6 & 2.9 & 52.0 & 1.0 & 100.0 & $\ldots$ & 52.3 & 40.0 \\
\hline Boyd, $\quad 1934$ & $1-2$ & 935 & 49.0 & 29.2 & 94.7 & 35.4 & 99.5 & 95.7 & 62.8 & 58.2 \\
\hline Boyd, & $1-5$ & 922 & 1.1 & 8.2 & 22.4 & 2.5 & 100.0 & 50.0 & 17.0 & 5.0 \\
\hline Chandler, 1934 & $1-1$ & 617 & 30.5 & 28.4 & 72.0 & 11.7 & 96.4 & 87.7 & 57.8 & 47.4 \\
\hline Chandler, 1934 & $2-4$ & 839 & 3.0 & 12.4 & 41.6 & 4.3 & 85.7 & 100.0 & 23.2 & 12.2 \\
\hline Sullivan, 1934 & $6-6$ & 649 & 48.5 & 17.7 & 81.3 & 61.5 & 100.0 & 97.2 & 59.4 & 55.3 \\
\hline Sullivan, 1934 & $5-3$ & 597 & 1.0 & 9.2 & 26.7 & 4.2 & 100.0 & 60.0 & 8.9 & 5.0 \\
\hline El Solyo, 1934 & $98-5$ & 1,035 & 24.5 & 17.9 & 67.1 & 17.8 & 98.5 & 90.2 & 49.2 & 50.7 \\
\hline El Solyo, 1934 & $99-4$ & 985 & 2.4 & 4.7 & 18.4 & 7.7 & 87.5 & 43.7 & 15.2 & 15.1 \\
\hline Chandler, 1935 & $1-20$ & 275 & 32.0 & 59.3 & 84.6 & 34.2 & 99.0 & 89.0 & 41.4 & 38.7 \\
\hline Chandler, 1935 & $2-20$ & 583 & 2.3 & 11.5 & 56.1 & 15.8 & 100.0 & 100.0 & 10.2 & 10.8 \\
\hline Bremer, $\quad 1935$ & $6-25$ & 492 & 28.6 & 31.6 & 86.5 & 42.2 & 99.0 & 80.8 & 40.0 & 45.8 \\
\hline Bremer, & $6-27$ & 870 & 5.5 & 10.3 & 50.0 & 5.7 & 88.0 & 34.8 & 26.5 & 22.7 \\
\hline Hill, & $6-41$ & 584 & 35.8 & 5.6 & 67.0 & 21.0 & 98.0 & 50.0 & 60.0 & 74.2 \\
\hline Hill, & $6-40$ & 1,162 & 5.4 & 9.4 & 58.3 & 8.1 & 97.3 & 61.5 & 26.9 & 26.4 \\
\hline
\end{tabular}

tion, and split-pit. Since there is a close association between gumming and the latter phenomena, a comparison of gummy and nongummy fruits involves some natural selection. It does not allow us to set up a balance sheet in which the proportion of all the split-pits or aborted embryos may be accounted for by the gummy and nongummy fruits.

Observation had indicated that trees with a large percentage of gummy fruits had more split-pits and aborted embryos among their nongummy fruits than did trees with a low percentage of gumming. Pairs of trees growing close together in the orchard were selected, one high in gumming, the other low. All their fruits were picked at maturity and graded according to gumming, split-pit, and embryo abortion. The data are presented in table 4. In 1933 three trees from the same orchard with different amounts of gummy fruits were harvested. In the other two years two trees in each of several orchards were used. 
A comparison of the percentage of split-pit among the nongummy fruits shows that in all cases except Hill, 1935, the tree producing the greater percentage of gummy fruits also has the greater percentage of split-pit among its nongummy fruits. As the data for embryo abortion among the nongummy fruits show in every case, the trees high in gumming have more aborted embryos among both split and nonsplit fruits than do trees low in gumming. A similar comparison of the gummy fruits does not show the same consistent differences. In most cases the percentage of embryo abortion is high and shows no differences between trees high and low in gumming. In a few cases among the nonsplit gummy fruit the embryo abortion is less for the trees with little gumming than for those with larger amounts.

The last two columns show what percentage of the total aborted embryos and split-pits on each tree is accounted for by gummy fruits. In each case of trees with much gumming a relatively larger proportion of all split-pits and aborted embryos is accounted for by the gummy fruits. A much smaller proportion is included in the trees with slight gumming. That is, in trees with little gumming, a greater proportion of all aborted embryos and split-pits will be found among the nongummy fruits than in trees with a high percentage of gumming. In all cases the gummy fruits account for a greater percentage of embryo abortion and split-pit than would occur unless these phenomena were definitely associated.

Table 4 adds evidence to that in table 3 regarding the close association of gumming, split-pit, and abortion. It presents further evidence regarding possible relations of these associated phenomena in showing that trees with a high percentage of gummy fruits usually have more splitpits and aborted embryos among their nongummy fruit than do trees with a lower percentage of gumming.

\section{INDIVIDUAL TREE PERFORMANCE}

As growers of the Phillips Cling have long known, individual trees vary greatly with respect to their percentage of gummy fruits. One influence on these variations is apparently the amount of crop that a tree has produced. Trees with light crops will usually have more gummy fruits than trees with heavy crops, and light-crop years are usually associated with more gumming than heavy-crop years. Other factors inherent in the individual tree, however, or characteristic of its environment might cause variations. Such a situation has been found in black-end of pears. ${ }^{(3)}$ If such a condition existed in the Phillips Cling it should be reflected in the performance of individual trees from year to year.

Method of Securing Data.-Many data obtained from mature fruit trees growing in orchard form are apparently associated with a high 
degree of variability unless large numbers of individuals are used. Data from individual trees were needed not only to evaluate their performance from year to year, but also to show how certain experimental manipulations affect the production of gumming. Grading the entire crop of each tree is a slow process and, during the rush that necessarily attends the harvesting of a canning peach crop, seriously limits the number of trees that may be used. Gummy fruits could be removed from the trees before harvest, but this procedure is also slow and limits the number. Counting the gummy fruits from the ground is relatively fast and had previously given excellent comparative data on the seasonal appearance of gumming (fig. 16). Gummy fruits are easily distinguished from the others, and the open structure of the peach tree lends itself to such a procedure. The data were obtained, with a hand counter, by walking back and forth and around the tree until the complete circuit had been made. The validity of this method has been checked in the following ways: (1) accuracy of duplication; (2) relation between the count from the ground and the number of gummy fruits actually on the tree.

Data on the foregoing points were obtained in the earlier years of the investigation coincidentally with the collection of data on the relation of split-pit, embryo abortion, and certain orchard practices to gumming. Information on accuracy of duplication was obtained during the routine collection of data concerning the effect of cultural practices. All the data were secured by the same two persons. Certain trees representing a high, a low, and an average number of gummy fruits were recounted, sometimes by the person making the original count, sometimes by the other. In 1930 and 1931, 49 trees were recounted. The count of gummy fruits varied from 1 to 107 per tree. The average number for the first count was 23.4 , with a probable error of \pm 1.8 ; that for the second was $25.2 \pm 1.92$. In 1933, 78 trees with a count varying between 1 and 112 gummy fruits per tree were counted twice. The first count gave an average of $36.5 \pm 2.28$; the second count $38.0 \pm 2.45$. None of these differences are significant. In 1933, 33 of the trees were counted by each of the workers. Because of the relatively small number of trees and the extremes in the number of gummy fruits per tree, Fisher's ${ }^{(4)}$ method for $t$ was used to evaluate these data. The differences between the counts of two operators gave a value for $t$ of 0.3341 , a value not significant. In 1932 and 1933 the gummy fruits on several hundred trees of the experimental plots were counted twice-once four or five weeks before harvest and again just before picking. The coefficient of correlation $r$ has been cal. culated for representative data of these two years. In 1932 the first count 
of 345 trees was made about July 20 ; the second about August 25. For these two counts $r$ equals 0.95 . In 1933 the first count of 183 trees was made about July 11; the second about August 15. For these data $r$ equals 0.93 .

Information has been obtained regarding the relation between the number of fruits as counted from the ground and the actual number on the tree. Findings have been expressed in the following manner: (1) correlation between the ground count and the percentage of gummy fruit; (2) correlation between the ground count and the number on the tree; (3) relation between the ground count and the number on the tree in terms of a factor to convert the ground count into the number on the tree. In 1930 the coefficient of correlation $r$ between the ground count and the percentage of gummy fruits for 68 trees in Sutter County was 0.85 ; for 80 trees in Sutter County in 1931, $r$ equaled 0.73 ; for 46 trees at the University Farm in 1932 it equaled 0.79. Considering the effect that the amount of fruit on a tree might have upon its tendency to produce gumming and upon the number of fruits available for gumming, these data probably show a close correspondence between the ground count and the percentage of gummy fruits. The following values for $r$ between the number of gummy fruits as counted from the ground and that actually on the tree have been obtained: Andross orchard (Sutter County), 1930, 50 trees, $r=0.877$; Galbraith orchard (Sutter County), 1930, 45 trees, $r=0.921$; Andross, 1931, 44 trees, $r=0.888$; Sutter County other than Andross, 63 trees, $r=0.891$; University Farm, 1932, 47 trees, $r=0.889$; Sutter County, 1933, 96 trees, $r=0.889$. These high values of $r$ indicate the close relation between the number of gummy fruits on the tree and the number seen from the ground. They should be higher than values of $r$ between the ground count and the percentage of gummy fruit, since neither variable is influenced by the size of the crop. The high value of $r$ indicates a low degree of scatter around the regression lines and a rather constant proportionality between the two variables. The ratio between the number of gummy fruits on the trees and the number counted from the ground has been calculated for each tree in 1932 and 1933. In 1932 the average of these ratios was $2.09 \pm 0.08$; in 1933 it was $2.16 \pm 0.06$. According to these data, only about half the gummy fruits are seen from the ground, but a very constant proportion is counted.

According to the foregoing data, counting of gummy fruits from the ground may be repeated with much accuracy; the correlation between these values and the percentage of gummy fruits or their actual number is high; and the ground count bears a constant ratio to the number on 
the tree. The data indicate that this method is very satisfactory for comparing the relative performance of individual trees or of experimental treatments in which large numbers of trees are included.

Performance of Individual Trees from Year to Year.-If the variations in the amount of gumming that trees produce are related to certain

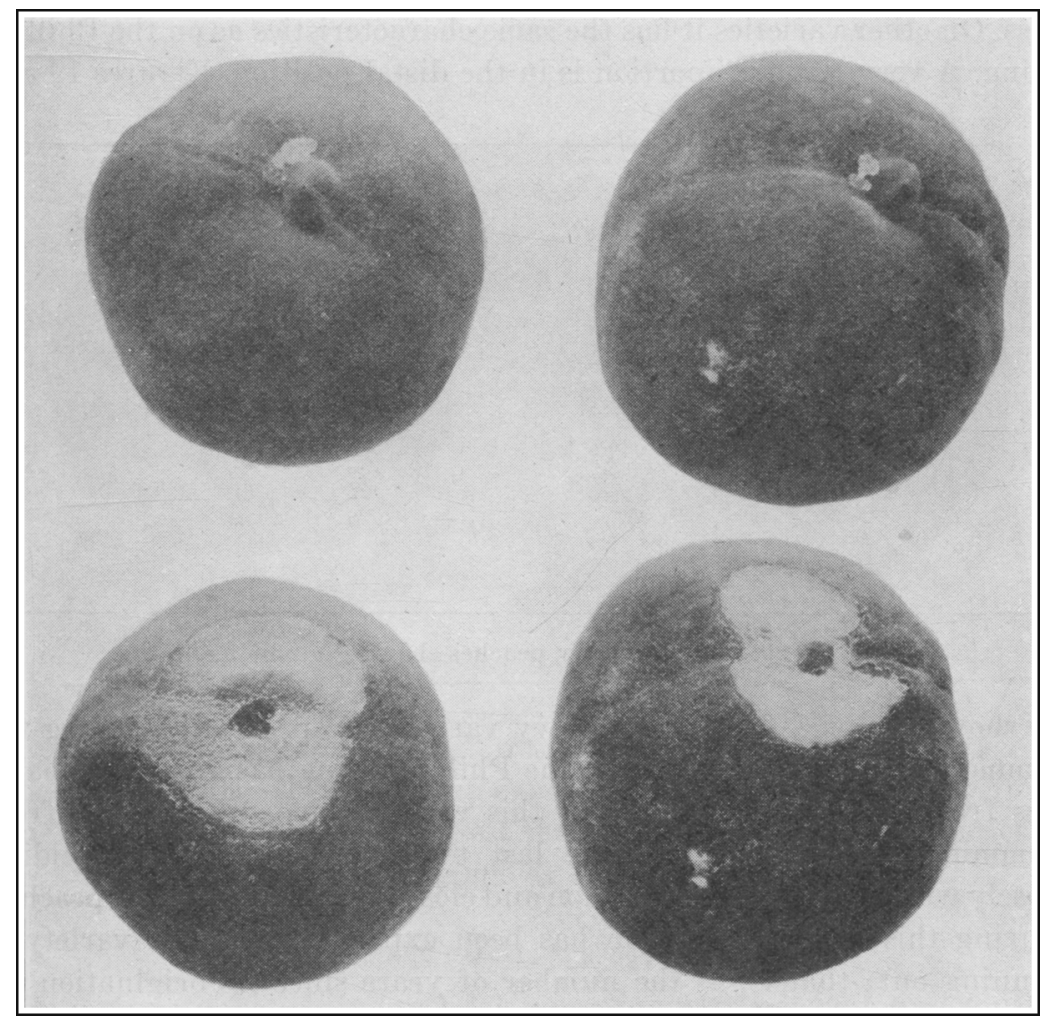

Fig. 19.-Mature Tuscan peaches showing gumming and the pocket in the flesh. The fruits in the lower row are the same as those in the upper row.

individual characteristics, behavior should be similar from year to year. Data have been obtained with respect to the number of gummy fruitsas counted from the ground-produced by the same trees in different years. The following coefficients of correlation have been calculated: Johnson orchard 1933 and 1934, 167 trees, $r=0.012$; Boyd orchard 1933 and 1934, 375 trees, $r=0.279$; El Solyo orchard 1933 and 1934, 356 trees, $r=0.02$; Bremer and Hill orchards 1935 and 1936, 293 trees, $r=0.326$. None of these values is significant, and the larger values of $r$ probably reflect certain differences in tree size. Judging from these data, 
the large variations in the number of gummy fruits are not associated with conditions that recur within individual trees year after year.

\section{GUMMING, A VARIETAL CHARACTERISTIC}

Although gumming seemingly can be found in any variety if enough fruits are examined, it does seem to be a varietal characteristic or weakness. On other varieties it has the same characteristics as on the Phillips Cling. A very large proportion is in the distal position. Figures 19 and

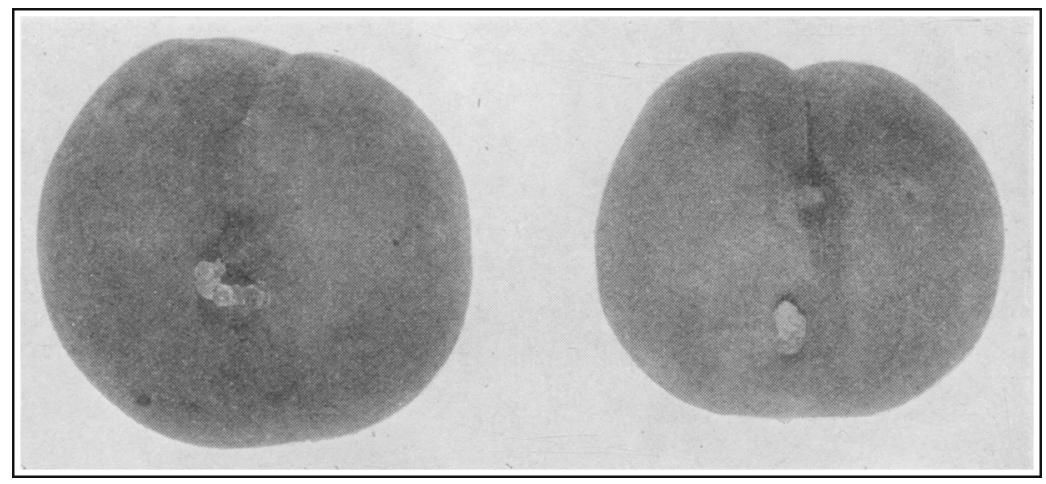

Fig. 20.-Mature Levy peaches showing gumming.

20 show it on the Tuscan and Levy varieties respectively. Among the common canning varieties, only the Phillips Cling has any appreciable loss from this cause. Growers of this variety have suffered loss from gumming especially during the last ten years, a period coinciding closely with that of overproduction and close grading of canning peaches. During this time the opinion has been expressed that the variety is running out; that is, as the number of years since its origination increases, undesirable characteristics begin to appear, and its value decreases. The idea of senile degeneration is not new. Bijouwer ${ }^{(1)}$ has referred to reported cases of 41 pears, 36 apples, and 1 plum among fruit varieties. He quotes Hedrick as saying, however, that he has never come across any evidence that fruit varieties have changed in the least for better or worse and that some of them were described by Pliny. The Phillips Cling originated about 1885 and therefore could not be considered old. Quantitative evidence on the production of gumming is available only for the last few years. These data show wide differences in the amount of gumming from year to year. Considering the lack of evidence regarding degeneration in other fruit varieties, mostly older than the Phillips Cling, it would seem preferable to consider gumming either 
as a varietal weakness, accentuated in recent years by different cultural practices, or as a characteristic of which the grower has become more conscious because of stricter grading practices. Figure 21 shows Phillips Cling peaches photographed in August, 1904. Figure 22 shows the same fruits halved along the suture line. The fruit on the right has typical distal gumming, with constriction around the distal end, a pocket in the flesh, and split-pit. The fruit on the left is a suture type that has re-

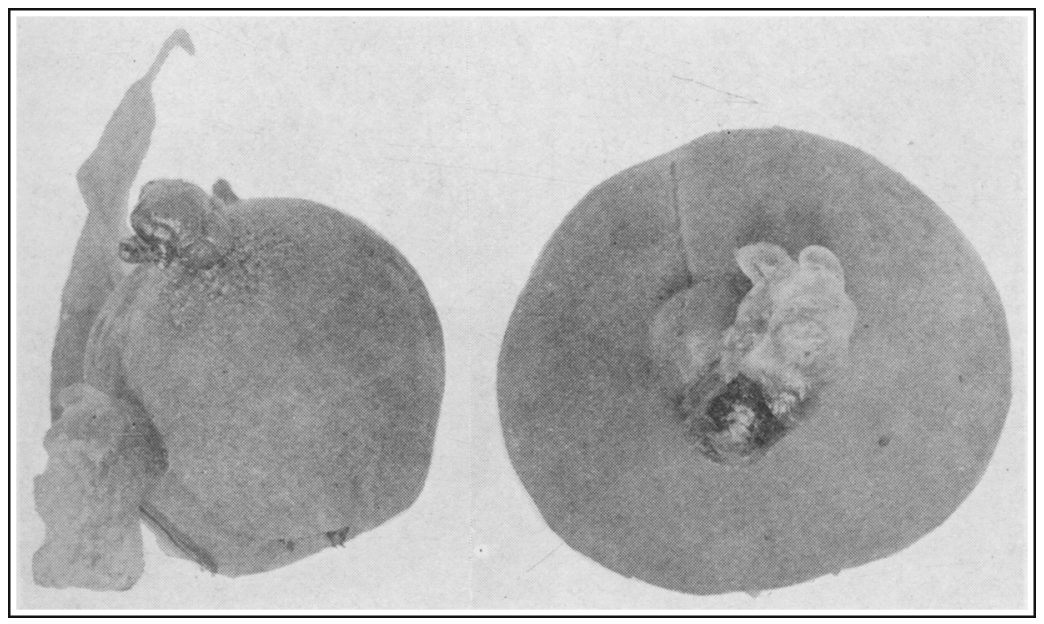

Fig. 21.-Phillips Cling peaches photographed in August, 1904.

mained on the tree. These, being exactly like many gummy fruits found during this investigation, suggest that the Phillips Cling was susceptible to this disturbance as long ago as 1904 .

\section{CONTROL METHODS}

The most satisfactory control for gumming may not be found until its exact cause is known. In effecting a control method, we have utilized the fact that the gumming begins at a definite time with respect to certain reference points in fruit development, such as the date when the pit is hardening on the tip. A large proportion of all the gumming will have occurred by the end of 35 to 40 days after this reference date. If thinning were delayed until after this time, it should be possible to remove the gummy fruits during the thinning process.

Experimental plots on the effect of different times of thinning have been carried out from 1931 through 1934. Thinning was done at three different times. The first time was before the pit had hardened, a period when-prior to the last few years-canning peaches were thinned. The 
second thinning was done at a time calculated to coincide with the rapid upswing in the curve for gumming (figs. 17 and 18) but before many gummy fruits had appeared. Leaving the crop on until this time would allow for the influence of the full crop from the time pit hardening began until gumming would be found. The third thinning was done 35 to 40 days after the reference date. This arrangement would allow for the

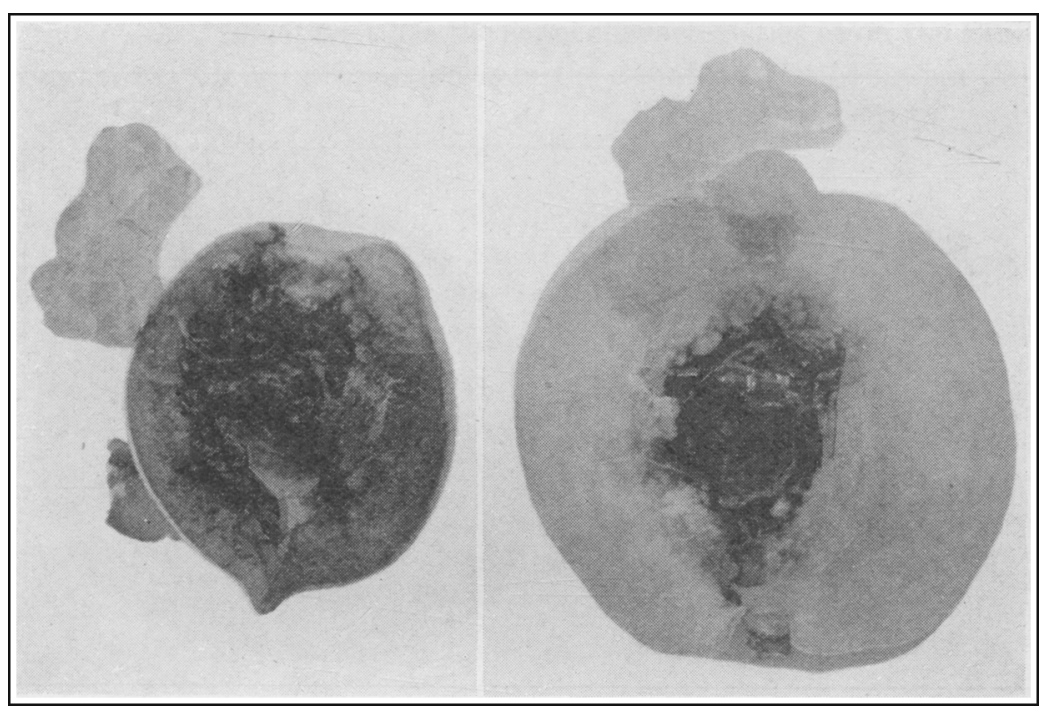

Fig. 22.-The same fruits as in figure 21 showing the pocket in the flesh.

influence of the full crop throughout the period before and during the appearance of the gumming and would also allow the gummy fruits to be removed in thinning.

Table 5 presents the data for 1932, 1933, and 1934 in terms of the average number of gummy fruits per tree as counted from the ground. This value is only approximately half the number of gummy fruits actually present on the tree. In 1932 the counting was done at three different times. The first count was made just before the last thinning. Data obtained at this time would show the influence of the full crop upon the production of gumming as compared with trees thinned before the pit had hardened and trees thinned after the pit had been hardening for about two weeks. The second count was made about a month after the first and the third, just before harvest. In 1933 and 1934 only two counts were made, at times comparable with the first and third counts of 1932.

In 1932 full bloom of the Phillips Cling was about March 15; May 18 was determined as the reference date. Figure 17 shows that the rapid 
TABLE 5

Efrect of Time of Thinning upon the Amount of Gum Produced (Data as average number of gummy fruits counted from the ground)

\begin{tabular}{|c|c|c|c|c|c|}
\hline Orchard & $\begin{array}{l}\text { Approxi- } \\
\text { mate } \\
\text { date of } \\
\text { thinning }\end{array}$ & $\begin{array}{c}\text { Number } \\
\text { of trees }\end{array}$ & $\begin{array}{l}\text { First } \\
\text { Count }\end{array}$ & $\begin{array}{l}\text { Second } \\
\text { Count }\end{array}$ & $\begin{array}{l}\text { Third } \\
\text { Count }\end{array}$ \\
\hline \multicolumn{6}{|c|}{$1932^{*}$} \\
\hline 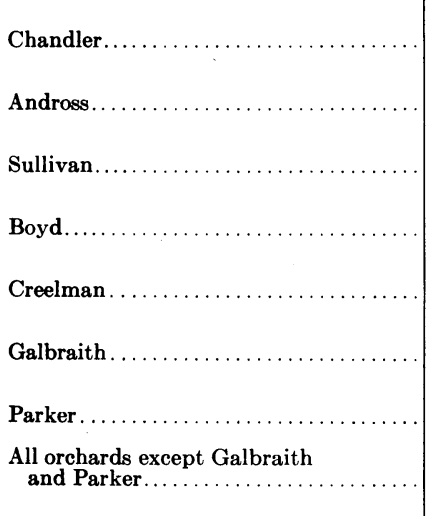 & $\begin{array}{ll}\text { April } & 30 \\
\text { May 28 } & 28 \\
\text { June 25 } \\
\text { April } 30 \\
\text { May 28 } \\
\text { June 25 } \\
\text { April } & 30 \\
\text { May 28 } \\
\text { June 25 } \\
\text { April } & 30 \\
\text { May 28 } \\
\text { June 25 } \\
\text { April } 30 \\
\text { May 28 } \\
\text { June 25 } \\
\text { April } 30 \\
\text { May 28 } \\
\text { June 25 } \\
\text { April } 30 \\
\text { May 28 } \\
\text { June 25 } \\
\text { April } 30 \\
\text { May 28 } \\
\text { June 25 }\end{array}$ & $\begin{array}{l}29 \\
36 \\
39 \\
15 \\
15 \\
14 \\
15 \\
15 \\
15 \\
15 \\
14 \\
15 \\
15 \\
15 \\
15 \\
15 \\
14 \\
15 \\
15 \\
15 \\
15 \\
80 \\
95 \\
83\end{array}$ & $\begin{array}{r}18.1 \\
15.0 \\
6.4 \\
28.8 \\
20.8 \\
6.9 \\
12.5 \\
4.5 \\
5.1 \\
19.9 \\
3.5 \\
5.7 \\
12.7 \\
18.9 \\
3.0 \\
37.8 \\
23.7 \\
35.0 \\
35.4 \\
21.5 \\
29.0 \\
20.4 \\
13.2 \\
5.6\end{array}$ & $\begin{array}{r}26.2 \\
20.1 \\
3.8 \\
25.6 \\
21.3 \\
6.8 \\
18.9 \\
15.1 \\
5.3 \\
29.3 \\
2.9 \\
7.7 \\
14.5 \\
22.0 \\
2.8 \\
\ldots . . \\
\ldots \ldots \\
\ldots . .5 \\
34.3 \\
19.3 \\
6.1 \\
26.1 \\
17.3 \\
4.4\end{array}$ & $\begin{array}{r}24.5 \\
19.5 \\
3.4 \\
24.0 \\
21.4 \\
7.3 \\
21.2 \\
14.4 \\
4.5 \\
31.8 \\
2.4 \\
14.0 \\
29.7 \\
3.5 \\
\ldots \ldots \\
\ldots \ldots \\
\ldots \ldots \\
\ldots \ldots \\
\ldots . . \\
2 . .6 \\
18.1 \\
4.4\end{array}$ \\
\hline \multicolumn{6}{|c|}{$1933 \dagger$} \\
\hline 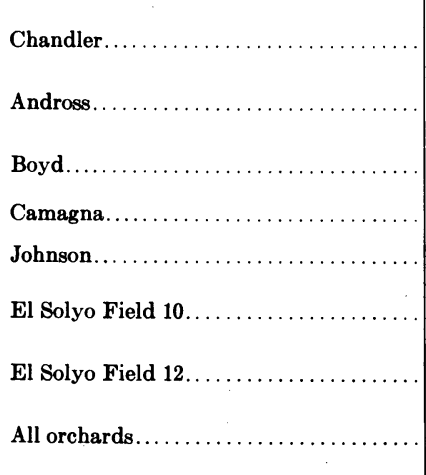 & $\begin{array}{lr}\text { May } & 29 \\
\text { June } & 21 \\
\text { July } & 3 \\
\text { May } & 20 \\
\text { June } & 20 \\
\text { July } & 3 \\
\text { May } & 20 \\
\text { June } & 20 \\
\text { July } & 8 \\
\text { May } & 20 \\
\text { July } & 5 \\
\text { June } & 9 \\
\text { June } & 27 \\
\text { May } & 16 \\
\text { June } & 10 \\
\text { July } & 5 \\
\text { May } & 16 \\
\text { June } & 10 \\
\text { July } & 5 \\
\text { May } & 20 \\
\text { June } & 20 \\
\text { July } & 5\end{array}$ & $\begin{array}{r}79 \\
109 \\
78 \\
144 \\
141 \\
150 \\
113 \\
91 \\
79 \\
22 \\
20 \\
98 \\
86 \\
171 \\
151 \\
162 \\
186 \\
181 \\
183 \\
715 \\
771 \\
758\end{array}$ & $\begin{array}{r}15.7 \\
8.9 \\
33.6 \\
13.7 \\
12.7 \\
19.6 \\
11.5 \\
9.2 \\
16.5 \\
5.0 \\
21.6 \\
5.4 \\
13.0 \\
8.3 \\
4.7 \\
17.8 \\
12.8 \\
8.8 \\
19.8 \\
12.5 \\
8.0\end{array}$ & $\begin{array}{r}17.6 \\
10.5 \\
7.1 \\
51.5 \\
22.2 \\
9.3 \\
24.1 \\
18.2 \\
6.6 \\
15.8 \\
4.5 \\
23.9 \\
5.9 \\
11.0 \\
9.0 \\
2.7 \\
16.3 \\
10.3 \\
3.0 \\
23.5 \\
14.9 \\
5.2\end{array}$ & \\
\hline \multicolumn{6}{|c|}{$1934 \ddagger$} \\
\hline El Solyo........ & $\begin{array}{l}\text { April } 30 \\
\text { May } 31 \\
\text { June } 20\end{array}$ & $\begin{array}{l}569 \\
548 \\
566\end{array}$ & $\begin{array}{r}19.9 \\
7.6 \\
10.6\end{array}$ & $\begin{array}{r}13.5 \\
6.9 \\
4.4\end{array}$ & \\
\hline
\end{tabular}

* First count made about June 13; second count July 21; third count August 23.

$\dagger$ First count made about June 30 ; second count September 1.

$\$$ First count made about June 14; second count August 13. 
upswing began 14 to 16 days after the latter date or around June 2, and by the end of the next 20 days more than 85 per cent of all gumming had occurred. In this year the first thinning, about April 30, came well before the beginning of pit hardening; the second thinning, about May 28, was some 10 days after the hardening had begun; and the last thinning, about June 25, occurred after much of the gumming had taken place. The data for all orchards except Galbraith and Parker show that, in comparison with the first thinning, the second thinning has reduced the amount of gumming about 30 per cent; and the last thinning about 83 per cent. The reduction in gumming associated with the second thinning must have been due to some influence that decreased the amount of gumming, since the thinning was done before gumming had begun and before any data were obtained. The data for the third thinning support this suggestion. The count of June 13, obtained before the last thinning, would show the effect of allowing the crop to remain on the tree during the time when gumming appears. The records for this date show that the gumming has been reduced 72 per cent and 57 per cent as compared with the trees thinned April 30 or May 28. The data obtained on July 21 and August 23 show that the gumming has been further reduced by removal of some gummy fruits. The trees thinned April 30 show an increase of about 28 per cent in the number of gummy fruits after June 13; those thinned on May 28 about 31 per cent; whereas those thinned June 25 show a decrease of about 21 per cent.

The Galbraith and Parker orchards, though included in the table, are omitted from the summary because they represent special cases. Both these orchards had very light erops, the first because of hail just after bloom, and the second because of low temperatures during blooming. These two orchards had considerably more gumming than did the others with normally heavy crops. In both, the only thinning required was an occasional breaking of clusters. The Galbraith orchard was not harvested and was neglected after midsummer. Only two plots were thinned-one on April 30 and one on May 28. This orchard presents an exception to the situation in which lack of thinning will prevent the appearance of a certain amount of gumming. In this case, where the difference in the amount of crop between the thinned and unthinned trees is not great, no decrease in the gumming has resulted from delaying the thinning. The smaller number of gummy fruits in the plot thinned May 28 is probably due to removal of some gummy fruits then present. The Parker orchard presents a similar ease with respect to the influence of the set on the amount of gumming. It differs from the Galbraith orchard with respect to the last thinning and subsequent care of the orchard. The thinning of June 25 illustrates the reduction in gumming that can be 
secured when the thinners are careful to remove as many gummy fruits as possible. The data for these two orchards substantiate our observations of individual trees that have large differences in the amount of fruit set.

The investigation in 1933 resembled that of 1932, but included many more trees. Full bloom was about March 21 ; the reference date May 31. The upswing in the appearance curve (fig. 17) began after June 15, 15 days after the reference date and continued for about 20 days, at which time nearly 90 per cent of all gumming had occurred. The second thinning, in some orchards, probably occurred after the gumming had begun and may influence the data, since some gummy fruits would be removed. When compared with the first thinning, the second has reduced the gumming about 36 per cent; the third about 78 per cent. The data obtained around June 30 show a progressive reduction in gumming according to the time of thinning. Trees to be thinned about July 5 show a reduction of about 60 per cent when compared with the earliest thinning and about 36 per cent when compared with the second.

In 1934 the investigation was limited to the El Solyo ranch. In this year full bloom was about March 14, and the reference date May 7. The first thinning was only about a week before the reference date; the second more than three weeks after it, at a time when some gumming had appeared; the last after most of the gumming had appeared. The data show the decrease in gumming caused by delayed thinning.

\section{DISCUSSION}

Gumming of the Phillips Cling is probably a varietal characteristic. Among the commonly grown commercial varieties, Phillips is the only one from which the growers suffer serious loss. Photographs in the files of the Division of Pomology record a disturbance of this variety in 1904 apparently exactly the same as that now occurring and serious enough at that time to merit attention and record. Gum of a similar appearancecolorless, clear, and occurring on the fruit-was described by Stone in 1890. ${ }^{(7)}$ He obtained gum of this nature from seedling peach trees growing in the southeastern states and differentiated between it and the colored gum occurring on the branches and trunks of the trees. A number of isolations from both the seeds and the gum-impregnated flesh of affected fruits have been sterile $;^{4}$ apparently no organism is associated with the disturbance.

As shown by certain characteristics of gumming described in this case history, there is considerable evidence regarding the varietal and physiological aspects of the disease.

${ }^{4}$ Personal correspondence with E. E. Wilson, Division of Plant Pathology, University of California, 1932. 
No other variety of peaches examined suffers nearly so much loss from gumming as the Phillips Cling. These other varieties, however, vary considerably in their tendency to produce gummy fruits. These variations apparently remain characteristics of these varieties from year to year. No organism has been found in the flesh or seeds of gummy fruits. The disease does not spread through the orchard over a period of years, as might be expected if some organism or virus were associated with the disease, when no control measures are applied.

Certain characteristics suggest its physiological nature. The segmented, twisted nature of the dorsal and distal types, their failure to vary in the point of emergence, the presence of a pocket in the flesh beneath the gumming, and the regular time of occurrence all suggest physiological and anatomical relations. The segmented gumming indicates that the segments may have emerged at successive intervals, separated by a space of time, during which the portion just exposed to the lower humidity of the air may have changed its physical state. The physical character of the gum varies from a liquidlike nature in a saturated atmosphere to a white crystallinelike nature when exposed to hot dry air, such as may occur during the hottest days. The twisted appearance of the gummy mass and the slitlike opening through which it had emerged suggest an internal pressure under which it was forced out of the fruit. The conception of internal pressure is substantiated by the fact that a fruit is rarely found with gum emerging at more than one point. The definite location at which the gum emerges suggests some constant anatomical relation. ${ }^{(\theta)}$

Similar considerations are indicated by the characteristic difference between the distal, dorsal, and ventral types. The distal and dorsal gummings always have pockets in the flesh; the dorsal type is always accompanied by the hump on the periphery; the ventral type never has a pocket in the flesh but always has a water-soaked area beneath the small, beadlike particles of gum. The regularity of occurrence with respect to fruit development and the short space of time in which so much of the gumming occurs are also of interest. It would seem that the time of occurrence and the period during which gumming appears would be less well defined unless some relation existed between its occurrence and certain phases in fruit or tree development. The correlation of split-pit, embryo abortion, and gumming, together with the variation in individual tree performance, points to some physiological relation.

Any explanation of the cause of gumming must consider the conditions described in the case history of the disease. Such a hypothesis must explain such phenomena as the restriction of the disease to the Phillips Cling variety, the close association of split-pit and embryo abortion with 
gumming, the regularity of the time of appearance with reference to certain developmental stages of the fruit, and the definite location of the point where the gum emerges. Until these phenomena are explained it would seem advisable to assume that the Phillips Cling may have certain varietal weaknesses which, under proper conditions, produce gumming on the fruit. If this were the case the best methods of control would be in eliminating, avoiding, or not contributing to such circumstances. Until these are well defined the control obtained by delaying the thinning until after most of the gumming has occurred seems to be the best method.

\section{SUMMARY}

At least four different types of gumming occur on the Phillips Cling peach. These differ in the place of occurrence on the fruit, the time during its development when they appear, and the economic importance to the grower.

Three of these types--the early suture, the dorsal and distal, and the late ventral-occur at a definite time in the development of the fruit.

There is a close association among gumming, split-pit, and embryo abortion. Split-pit and embryo abortion of nongummy fruits are apparently associated with the tendency to produce gumming of the tree from which they came.

Counting the number of gummy fruits that could be seen by an observer standing on the ground was found to be a very satisfactory method of obtaining data, especially with large numbers of trees.

Delaying the thinning until about 5 weeks after the pit was beginning to harden on the tip has controlled gumming satisfactorily.

The probable physiological nature of the disease is discussed. 


\section{LITERATURE CITED}

${ }^{1}$ Bijouwer, A. P. C.

1931. Old and new standpoints on senile degeneration. Jour. Pomol. and Hort. Sci. 9:122-44.

${ }^{2}$ Davis, L. D.

1932. The gumming of Phillips Cling peaches. Amer. Soc. Hort. Sci. Proc. 29:27.

${ }^{3}$ Davis, L. D. and W. P. TuFrs.

1935. Black-end of pears III. Amer. Soc. Hort. Sci. Proc. 33:304-15.

${ }^{4}$ Fisher, R. A.

1930. Statistical methods for research workers. 283 p. Oliver and Boyd, London.

${ }^{5}$ Lilleland, Omund.

1933. Growth study of the peach fruit. Amer. Soc. Hort. Sci. Proc. 29:8-12.

${ }^{6}$ Ragland, C. H.

1934. The development of the peach fruit, with special reference to split-pit and gumming. Amer. Soc. Hort. Sci. Proc. 31:1-21.

${ }^{7}$ Stone, W. E.

1890. Upon the carbohydrates of peach gum. Amer. Chem. Jour. 12:435-40.

8 TUKey, H. B.

1933. Embryo abortion in early-ripening varieties of Prunus avium. Bot. Gaz. 44:433-68.

๑ TUKEY, H. B.

1933. Growth of the peach embryo in relation to growth of fruit and season of ripening. Amer. Soc. Hort. Sci. Proc. 30:209-18. 